\title{
Exploring the Use of Conformationally Locked Aminoglycosides as a New Strategy to Overcome Bacterial Resistance
}

\author{
Agatha Bastida, ${ }^{\dagger}$ Ana Hidalgo, ${ }^{\dagger}$ Jose Luis Chiara, ${ }^{\dagger}$ Mario Torrado, ${ }^{\dagger}$ \\ Francisco Corzana, ${ }^{\dagger}$ Jose Manuel Pérez-Cañadillas, ${ }^{\ddagger}$ Patrick Groves,, \\ Eduardo Garcia-Junceda, ${ }^{\dagger}$ Carlos Gonzalez, ${ }^{\ddagger}$ Jesús Jimenez-Barbero, ${ }^{\S}$ and \\ Juan Luis Asensio*,† \\ Contribution from the Instituto de Química Orgánica General (CSIC), 28006 Madrid, Spain, \\ Instituto de Química Física Rocasolano (CSIC), Madrid 28006, Spain, and Centro de \\ Investigaciones Biológicas (CSIC), Madrid 28040, Spain \\ Received June 30, 2005; E-mail: iqoa110@iqog.csic.es
}

\begin{abstract}
The emergence of bacterial resistance to the major classes of antibiotics has become a serious problem over recent years. For aminoglycosides, the major biochemical mechanism for bacterial resistance is the enzymatic modification of the drug. Interestingly, in several cases, the oligosaccharide conformation recognized by the ribosomic RNA and the enzymes responsible for the antibiotic inactivation is remarkably different. This observation suggests a possible structure-based chemical strategy to overcome bacterial resistance; in principle, it should be possible to design a conformationally locked oligosaccharide that still retains antibiotic activity but that is not susceptible to enzymatic inactivation. To explore the scope and limitations of this strategy, we have synthesized several aminoglycoside derivatives locked in the ribosomebound "bioactive" conformation. The effect of the structural preorganization on RNA binding, together with its influence on the aminoglycoside inactivation by several enzymes involved in bacterial resistance, has been studied. Our results indicate that the conformational constraint has a modest effect on their interaction with ribosomal RNA. In contrast, it may display a large impact on their enzymatic inactivation. Thus, the work presented herein provides a key example of how the conformational differences exhibited by these ligands within the binding pockets of the ribosome and of those enzymes involved in bacterial resistance can, in favorable cases, be exploited for designing new antibiotic derivatives with improved activity in resistant strains.
\end{abstract}

\section{Introduction}

Aminoglycoside antibiotics are highly potent, wide-spectrum bactericidals. ${ }^{1-4}$ These drugs bind to the decoding region aminoacyl-tRNA site (A-site) inducing codon misreading and inhibiting translocation, eventually resulting in cell death. ${ }^{1-4}$ From a chemical point of view, aminoglycosides are polycationic oligosaccharides carrying several hydroxyl and amino functional groups. Most include one or more amino sugars attached to a 2-deoxystreptamine ring (ring II in Scheme 1). The structures of several aminoglycosides, such as gentamycin, tobramycin, and paromomycin, bound to the target ribosomal A-site RNA have been determined recently by both X-ray and NMR methods. ${ }^{5-7}$ These structures have provided an extremely

\footnotetext{
† Instituto de Química Orgánica General (CSIC), Madrid 28006, Spain.

$\doteqdot$ Instituto de Química Física Rocasolano (CSIC), Madrid 28006, Spain.

$\S$ Centro de Investigaciones Biológicas (CSIC), Madrid 28040, Spain.

(1) Walter, F.; Vicens, Q.; Westhof, E. Curr. Opin. Chem. Biol. 1999, 3, 694704.

(2) Hermann, T. Angew. Chem., Int. Ed. 2000, 39, 1890-1905.

(3) Schroeder, R.; Waldsich, C.; Wank, H. EMBO J. 2000, 19, 1, 1-9.

(4) Sucheck, J. S.; Wong, C. H. Curr. Opin. Chem. Biol. 2000, 4, 678-686.

(5) Carter, A. P.; Clemons, W. M.; Brodersen, D. E.; Morgan-Warren, R. J.; Wimberly, B. T.; Ramakrishnan, V. Nature 2000, 407, 340-348.
}

detailed knowledge about the interactions that stabilize the drug/ RNA complexes.

Several years after the introduction of aminoglycosides in human antibacterial chemotherapy, resistant organisms began to appear. Indeed, the emergence of bacterial resistance to the major classes of antibiotics has become a serious problem over recent years. ${ }^{89}$ Acquired resistance to aminoglycoside antibiotics can occur via three different mechanisms: mutation of the ribosomal target, reduced permeability for the antibiotics, and enzymatic modification of the drugs, thus leading to inactivation. The most prevalent source of clinically relevant resistance is conferred by the third mechanism, the enzymatic inactivation of the drugs. ${ }^{8,9}$ Enzymes involved in bacterial defense against aminoglycoside antibiotics can be broadly classified as $N$ acetyltransferases (AACs), $O$-adenyl transferases (ANTs), and

(6) (a) Vicens, Q.; Westhof, E. Structure 2001, 9, 647-658. (b) Vicens, Q.; Westhof, E. Chem. Biol. 2002, 9, 747-755.

(7) (a) Yoshizawa, S.; Fourmy, D.; Puglisi, J. D. EMBO J. 1998, 17, 22, 64376448. (b) Fourmy, D.; Recht, M. I.; Blanchard, A. C.; Puglisi, J. D. Science 1996, 274, 1367-1371. (c) Lynch, S. R.; Gonzalez, R. L., Jr.; Puglisi, J. D. Structure 2003, 11, 43-53.

(8) Magnet, S.; Blanchard, J. Chem. Rev. 2005, 105, 477-497.

(9) Smith, C. A.; Baker, E. N. Curr. Drug Targets 2002, 2, 143-160. 
Scheme 1. Schematic Representation of the Conformational Differences (Highlighted with a Dotted Box) Exhibited by Aminoglycosides in the Binding Pockets of RNA and Some of the Enzymes Involved in Bacterial Resistance ${ }^{a}$
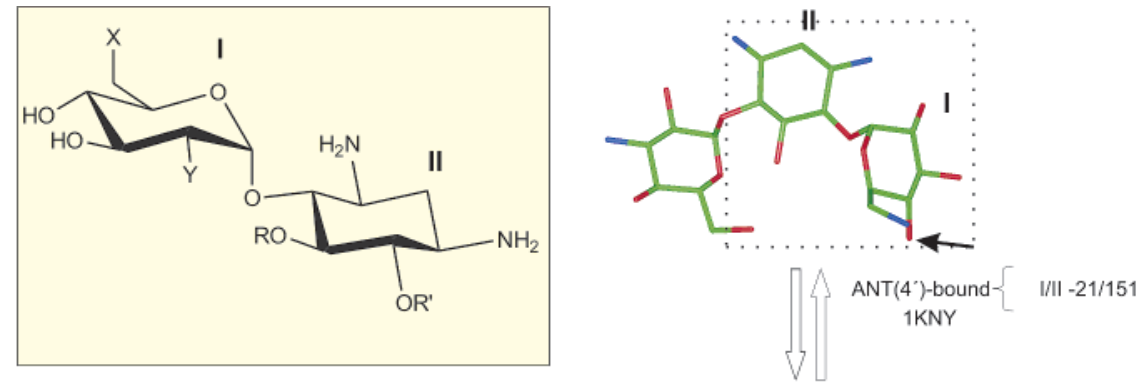

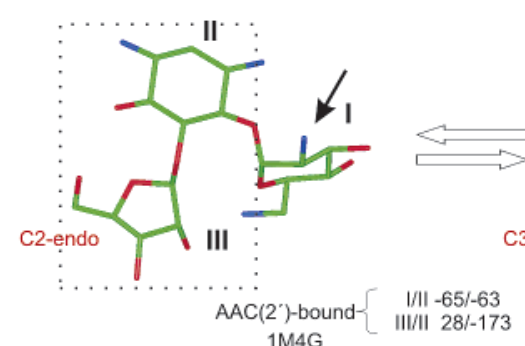

$1 \mathrm{M} 4 \mathrm{G}$

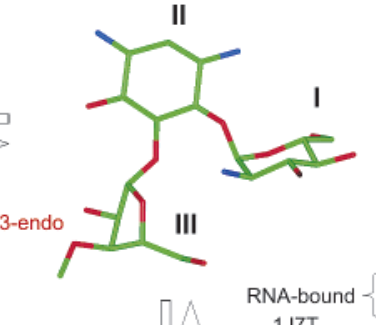

$1 \mathrm{~J} 7 \mathrm{~T}$

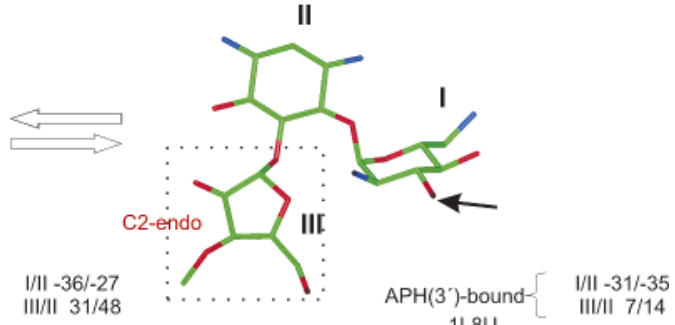

$1 \mathrm{LBU}$
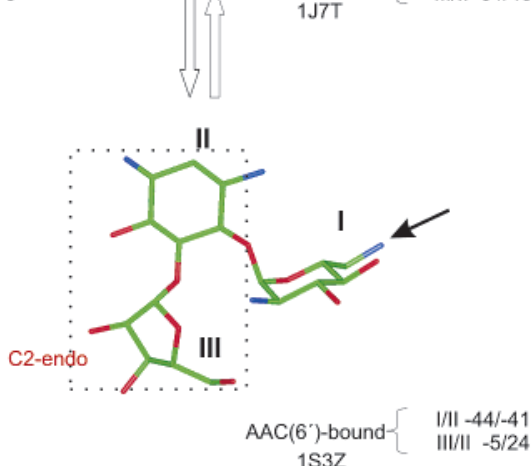

$1 \mathrm{~S} 3 \mathrm{Z}$

${ }^{a}$ The glucose, 2-deoxy-streptamine, and ribose units are numbered as I, II, and III, respectively. The values of the glycosidic torsion angles $\Phi(\mathrm{H} 1-$ $\mathrm{C} 1-\mathrm{Ox}-\mathrm{Cx})$ and $\Psi(\mathrm{Hx}-\mathrm{Cx}-\mathrm{O} 1-\mathrm{C} 1)$ for each glycosidic linkage in the bound state, together with the pdb codes of the complexes, are indicated. The position of the aminoglycoside modified by the enzyme is marked by an arrow. A schematic representation of the Glc $\alpha(1-4) 2$-deoxy-streptamine fragment present in neomycin $\left(\mathrm{X}=\mathrm{NH}_{2}, \mathrm{Y}=\mathrm{NH}_{2}, \mathrm{R}=2\right.$,6-diamino-2,6-dideoxy-L-Ido $\left.\beta(1-3) \mathrm{Rib}, \mathrm{R}^{\prime}=\mathrm{H}\right)$, paromomycin $\left(\mathrm{X}=\mathrm{OH}, \mathrm{Y}=\mathrm{NH}_{2}, \mathrm{R}=2,6\right.$-diamino2,6-dideoxy-L-Ido $\left.\beta(1-3) \mathrm{Rib}, \mathrm{R}^{\prime}=\mathrm{H}\right)$, ribostamycin $\left(\mathrm{X}=\mathrm{NH}_{2}, \mathrm{Y}=\mathrm{NH}_{2}, \mathrm{R}=\mathrm{Rib}, \mathrm{R}^{\prime}=\mathrm{H}\right)$, and kanamycin $\left(\mathrm{X}=\mathrm{NH}_{2}, \mathrm{Y}=\mathrm{OH}, \mathrm{R}=\mathrm{H}, \mathrm{R}^{\prime}=3\right.$-amino3 -deoxy- $\alpha$-Glc) is shown in the top left-hand corner.

$O$-phosphotransferases (APHs). It is evident that a detailed knowledge of the structures of these enzymes and their interactions with the drugs should provide a framework that will facilitate the rational design either of novel aminoglycosides, not susceptible to modification, or of inhibitors of these enzymes, which could be administered in tandem with existing aminoglycosides. Indeed, the search for new derivatives not susceptible to modification by bacterial defense proteins constitutes an active field of research. ${ }^{10-13}$

The 3D structures of several aminoglycoside-enzyme complexes have been described recently by X-ray methods. ${ }^{9}, 14$ Interestingly, in some cases, the 3D structure of the antibiotic

(10) (a) Kondo, S.; Iinuma, K.; Yamamoto, H.; Maeda, K.; Umezawa, H. J. Antibiot. 1975, 26, 412-417. (b) Kondo, S.; Hotta, K. J. Infect. Chemother. 1999, $5,1$.

(11) Inoue, M.; Nonoyama, M.; Okamoto, R.; Ida, T. Drugs Exp. Clin. Res. 1994, 20, 233-239.

(12) Fujimura, S.; Tokue, Y.; Takahashi, H.; Nukiwa, T.; Hisamichi, K.; Mikami, T.; Watanabe, A. J. Antimicrob. Chemother. 1998, 41, 495-499.

(13) (a) Roestamadji, J.; Graspas, I.; Mobashery, S. J. Am Chem. Soc. 1995, 117, 11060-11069. (b) McKay, G. A.; Roestamadji, J.; Mobashery, S.; Wright, G. D. Antimicrob. Agents Chemother. 1996, 40, 2648. (c) Haddad, J.; Vakulenko, S.; Mobashery, S. J. Am. Chem. Soc. 1999, 121, 1192211923. (d) Grapsas, I.; Lerner, S. A.; Mobashery, S. Arch. Pharm. 2001, $334,295$.

(14) Vicens, Q.; Westhof, E. Biopolymers 2003, 70, 42-57. in the enzyme binding site significantly differs from that observed in the corresponding aminoglycoside/A-site RNA complex (see Scheme 1). For example, Staphylococcus aureus ANT(4') selects a high energy conformation of the ligand, kanamycin. ${ }^{15}$ In particular, the Glc $\alpha(1-4)$-2-deoxy streptamine fragment (numbered as units I and II in Scheme 1), present in all aminoglycosides with different patterns of amination/ hydroxylation at the glucose unit (I), adopts an anti- $\Psi$ geometry $(\Phi / \Psi,-21 / 151)$. In contrast, for tobramycin and paromomycin, the analogous glycosidic linkage is defined by a syn- $\Psi$ conformation $(\Phi / \Psi \approx-40 /-30)$ in the RNA-bound state. The "syn$\Psi$ " geometry also constitutes the most populated minimum for the free antibiotics, according to NMR data. ${ }^{16}$ The drug conformation selected by ANT $\left(4^{\prime}\right)$ represents a high-energy minimum that must be stabilized by specific aminoglycoside-protein interactions. In a similar way, the X-ray structure of Mycobacterium tuberculosis $\mathrm{AAC}\left(2^{\prime}\right)$ in complex with ribostamycin shows that the $\operatorname{Rib} \beta(1-5)-2$-deoxy streptamine fragment (num-

(15) Pedersen, L. C.; Benning, M. M.; Holden, H. M. Biochemistry 1995, 34, 13305-13311.

(16) Asensio, J. L.; Hidalgo, A.; Cuesta, I.; González, C.; Cañada, J.; Vicent, C.; Chiara, J. L.; Cuevas, G.; Jiménez-Barbero, J. Chem. Eur. J. 2002, 8, 22, 5228-5240. 
Chart 1. Schematic Representation of the Proposed Structure-Based Chemical Strategy to Overcome Bacterial Resistance

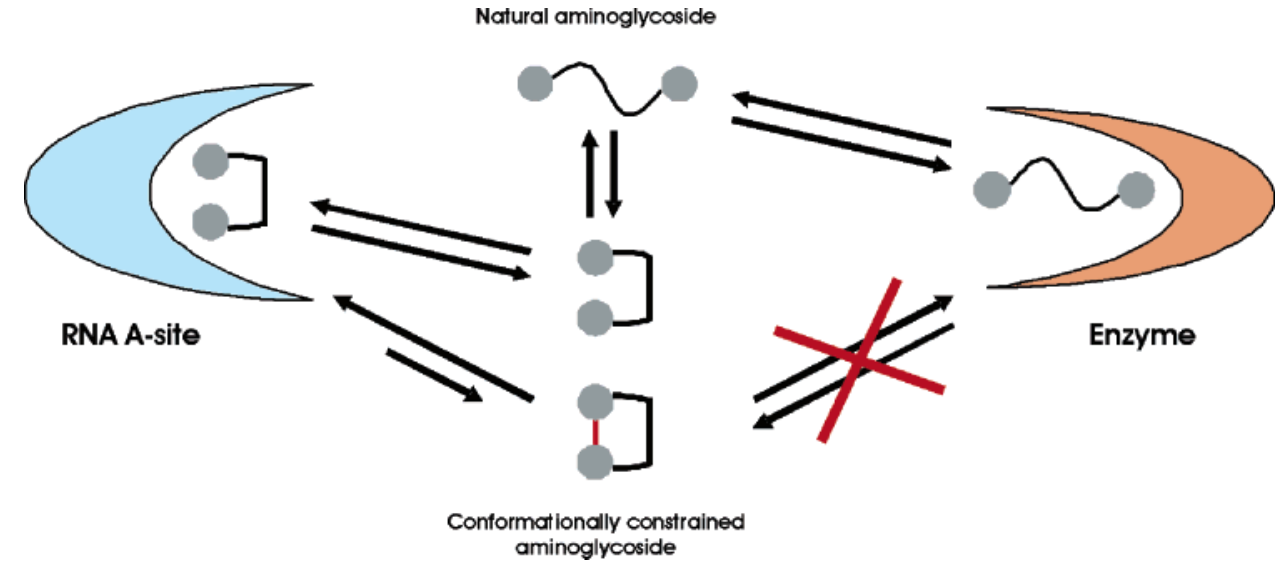

bered as units III and II in Scheme 1) also adopts a high energy "anti- $\Psi$ " conformation $(\Phi / \Psi=28 /-173) .{ }^{17}$ This geometry is significantly different to the bioactive "syn- $\psi$ " orientation adopted by the same glycosidic bond in the paromomycin/Asite complex. ${ }^{5,6}$ An additional key example of conformational differences of aminoglycosides between the RNA- and proteinbound states is provided by the recently reported structure of the Salmonella enteritidis $\mathrm{AAC}\left(6^{\prime}\right)$ in complex with ribostamycin. ${ }^{18}$ In this case, the $\operatorname{Rib} \beta(1-5)$-2-deoxy streptamine fragment (units III and II in Scheme 1) of the oligosaccharide presents a rather unusual nonexo-anomeric conformation (characterized by a $\Phi$ angle of $-5^{\circ}$ ). In addition, the furanose ring (numbered as III in Scheme 1) is bound in a C2-endo conformation, in contrast with the C3-endo geometry selected by the ribosomal RNA. A similar furanose puckering is also recognized by the Enterococcus faecalis $\mathrm{APH}\left(3^{\prime}\right)$ enzyme according to the X-ray structure of its complex with neomycinB. ${ }^{19}$

The different 3D-shapes adopted by aminoglycosides in the RNA- and enzyme-bound states suggest a possible structurebased chemical strategy to obtain antibiotics with a better activity against resistant bacteria. Assuming that, in these cases, some degree of conformational distortion of the substrates is required for enzymatic activity, it should be possible to design a conformationally locked oligosaccharide that still retains antibiotic activity but that is not susceptible to enzymatic inactivation (Chart 1). ${ }^{20}$

To test this hypothesis, we have designed and synthesized several neomycin-B analogues locked in the RNA-bound (bioactive) structure of the antibiotic. ${ }^{21}$ Thus, we have studied the effect that structural preorganization has on the strength of the aminoglycoside-RNA interaction. In a second step, we have determined the susceptibility of the conformationally locked derivatives to enzymatic inactivation, employing the enzymes Staphylococcus aureus ANT(4'), Mycobacterium tuberculosis $\mathrm{AAC}\left(2^{\prime}\right)$, and Enterococcus faecalis $\mathrm{APH}\left(3^{\prime}\right)$ as model systems.

(17) Vetting, M. W.; Hegde, S. S.; Javid-Majd, F.; Blanchard, J. S.; Roderick, S. L. Nat. Struct. Biol. 2002, 9, 653-658.

(18) Vetting, M. W.; Magnet, S.; Nieves, E.; Roderick, S. L.; Blanchard, J. S. Chem. Biol. 2004, 11, 565-573.

(19) Fong, D. H.; Berghuis, A. M. EMBO J. 2002, 21, 2323-2331.

(20) A key example of how the enzymatic activity can be modulated by small conformational preferences of the substrates was reported recently: Galan, M. C.; Venot, A. P.; Boons, G. J. Biochemistry 2003, 42, 8522-8529.

(21) A preliminary communication on some of the aspects described above has been recently published: Asensio, J. L.; Hidalgo, A.; Bastida, A.; Torrado, M.; Corzana, F.; García-Junceda, E.; Cañada, J.; Chiara, J. L.; JiménezBarbero, J. J. Am. Chem. Soc. 2005, 127, 8278-8279.
The design of our conformationally constrained aminoglycosides is based on the structural information available for the RNA-paromomycin complex. ${ }^{5,6}$ The structure of neomycin-B (1) along with the numbering employed for the different sugar units along this manuscript (I, II, III, and IV for the glucose, 2-deoxy-streptamine, ribose, and idose units, respectively) is shown in Scheme 2. It is known that positions $05_{\text {III }}$ and $\mathrm{N} 2$ I are hydrogen bonded within the ribosome bound state. Thus, in our analogues, this interaction has been replaced by either a direct covalent bond, as in $\mathbf{2}$, a two-methylene bridge, as in $\mathbf{3}$, or by a salt bridge, as in 4 (see Scheme 2).

It should be pointed out that $\mathrm{OH} 5_{\mathrm{III}}$ is involved in RNA recognition ${ }^{5,6}$ and might also have an influence on the enzymatic inactivation of the antibiotics. Since cyclization of neomycin-B to give $\mathbf{2}$ or $\mathbf{3}$ required the removal of this $\mathrm{OH}$ group, the deoxyderivatives $\mathbf{5}$ and $\mathbf{6}$ were also synthesized as controls, to isolate the effect of rigidification.

In the first part of the manuscript we present a detailed description of the synthesis of the proposed neomycin-B derivatives. The next section deals with the structural NMR analysis of the obtained aminoglycosides. This study, essential in order to establish any structure-activity relationship, shows that, as expected, the obtained antibiotics exhibit a significantly reduced flexibility with respect to natural neomycin-B and, in addition, closely resemble its bioactive ribosome-bound conformation. In the next two sections the effect of the conformational restriction on the RNA binding properties and the biological activity of these analogues is determined. Finally the susceptibility of the obtained derivatives to enzymatic modification has been tested employing three different enzymes involved in bacterial resistance. This final analysis suggests that conformational restriction might constitute a useful approach to prevent aminoglycoside inactivation by bacterial defense proteins.

\section{Results and Discussion}

Synthesis of the Proposed Neomycin-B Derivatives. A. Synthesis of Neomycin-B Conformationally Constrained Analogue 2. Compound 2 was prepared following the simple four-step procedure shown in Scheme 3. Thus, the hexa- $N$ (benzyloxycarbonyl) derivative (7), readily prepared from neomycin-B (1), ${ }^{22}$ was treated with 2,4,6-triisopropylbenzenesulfonyl chloride in pyridine ${ }^{23}$ to yield the primary sulfonate

(22) Kumar, V.; Remers, W. A. J. Org. Chem. 1981, 46, 4298-4300.

(23) Michael, K.; Wang, H.; Tor, Y. Bioorg. Med. Chem. 1999, 7, 1361-1372. 
Scheme 2. Schematic Representation of the Target Conformationally Locked Aminoglycosides $(\mathbf{2}-\mathbf{4})$ and the Deoxy Derivatives $(\mathbf{5}, \mathbf{6})^{a}$

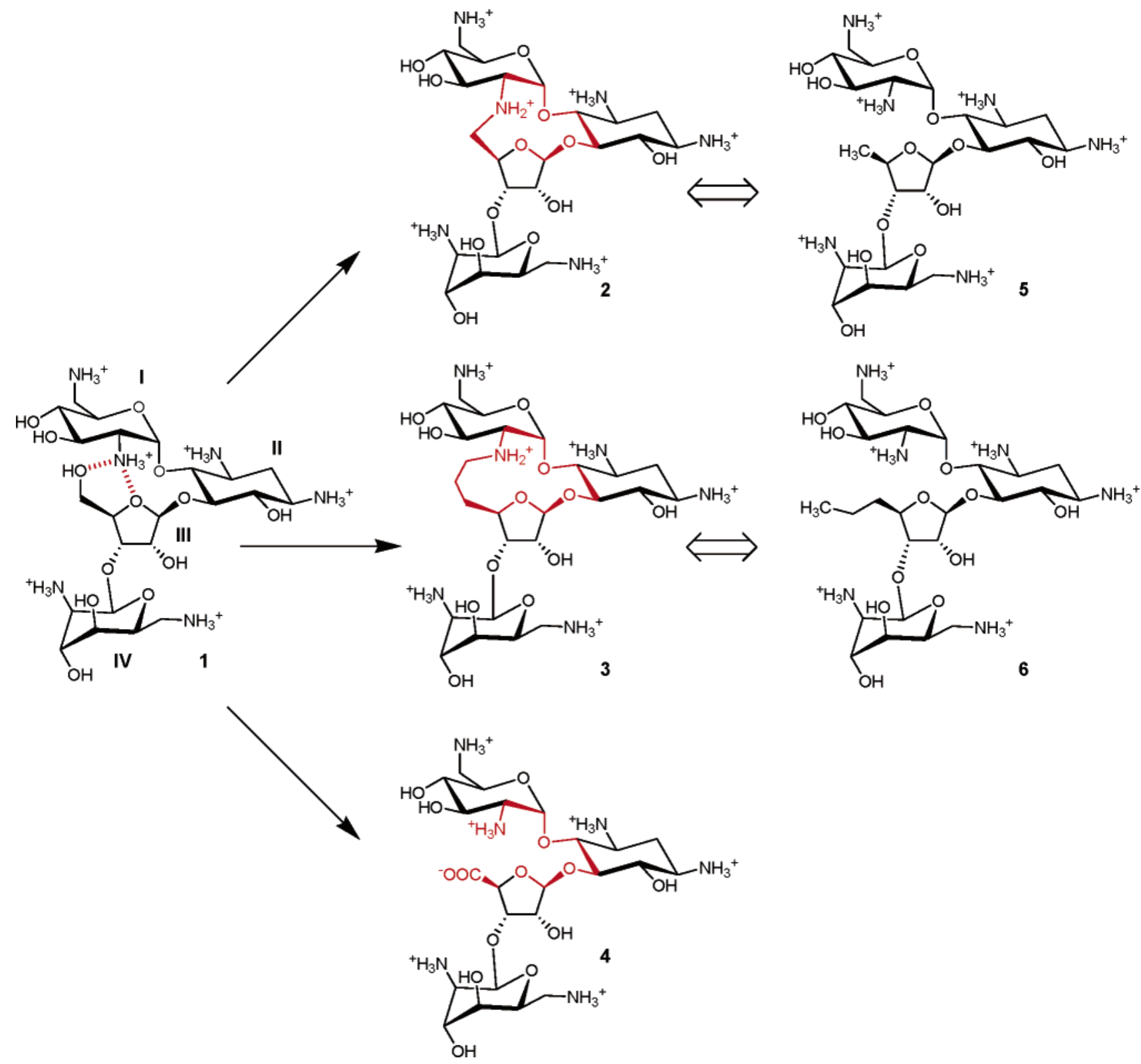

${ }^{a}$ The numbering employed for the different sugar units is indicated for neomycin-B (compound $\mathbf{1}$ ).

(8), regioselectively. Deprotection of the amino groups by palladium-catalyzed hydrogenolysis in $\mathrm{MeOH} /$ trifluoroacetic acid gave crude sulfonate (9) that smoothly cyclized in a highly regioselective way by mild heating in water at $\mathrm{pH} 7.0$ to give 2 in $56 \%$ yield.

B. Synthesis of Neomycin-B Conformationally Constrained Analogue 3. The synthesis of compound $\mathbf{3}$ is shown in Scheme 4. The key step involves a two-carbon atom elongation of ring III side chain through a Wittig-type reaction on aldehyde 12. The following four-step strategy was used to obtain this aldehyde in good yield. First, regioselective protection of the primary hydroxyl group of 7, by treatment with triisopropylsilyl trifluoromethanesulfonate and 2,6-lutidine, followed by acetylation of the secondary hydroxyl groups gave compound 10, which was desilylated by treatment with HF. pyridine to give 11. Finally, oxidation of 11 using the DessMartin periodinane gave the required aldehyde $\mathbf{1 2}$ in $57 \%$ overall yield from $\mathbf{7}$. Treatment of $\mathbf{1 2}$ with (methoxycarbonylmethylen)- triphenylphosphorane in acetonitrile gave the corresponding $\alpha, \beta$ unsaturated ester 13, which was reduced with $\mathrm{NaBH}_{4}$ in the presence of catalytic $\mathrm{LiCl}$ to give alcohol $\mathbf{1 4}$ in $89 \%$ yield. Initially, we tried the selective activation of the primary alcohol in 14, by treatment with 2,4,6-triisopropylbenzenesulfonyl chloride in pyridine. However, the low regioselectivity obtained in the reaction forced us to use a three-step strategy similar to that described above. Thus, regioselective protection of the primary hydroxyl group in $\mathbf{1 4}$ as a triisopropylsilyl ether, yielded derivative 15. Acetylation of the secondary hydroxyl groups followed by desilylation gave derivative 16, which was transformed into the corresponding primary sulfonate by treatment with $p$-toluenesulfonyl chloride in pyridine. Finally, clean deacetylation of this derivative was best performed by mild KCN-catalyzed methanolysis, ${ }^{24}$ to give 17 . The carbamate groups were removed by palladium-catalyzed hydrogenolysis

(24) Mori, K.; Tominaga, M.; Takigawa, T.; Matsui, M. Synthesis 1973, 790791. 


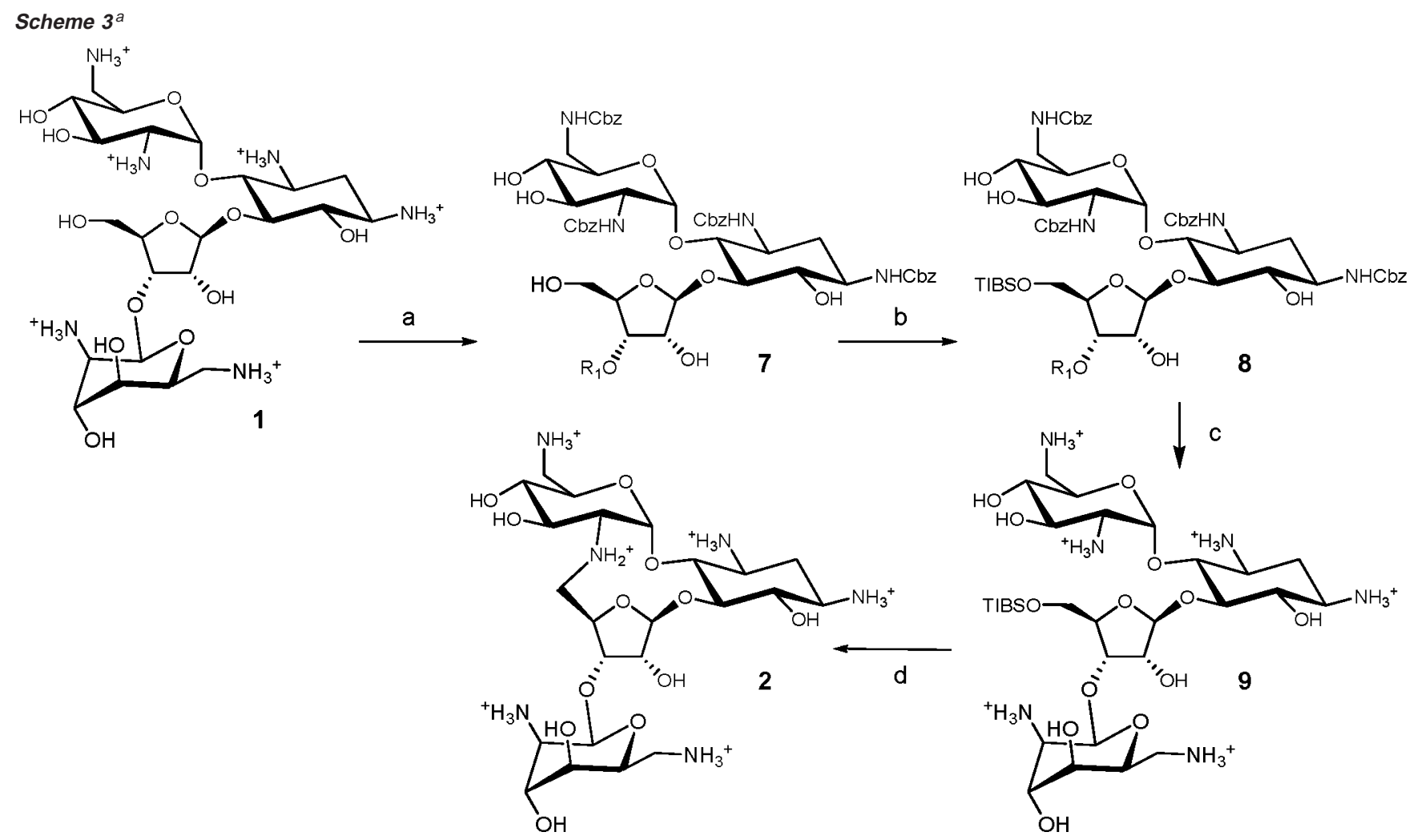

${ }^{a}$ (a) $\mathrm{CbzCl}, \mathrm{Na}_{2} \mathrm{CO}_{3}, \mathrm{MeOH} / \mathrm{H}_{2} \mathrm{O} 3: 1,0{ }^{\circ} \mathrm{C}, 3 \mathrm{~h}, 92 \%$; (b) 2,4,6-triisopropylbenzenesulfonyl chloride (TIBSCl), Py, rt, $72 \mathrm{~h}, 44 \%$; (c) $\mathrm{H}_{2}$ (1 atm), $\mathrm{Pd} / \mathrm{C}$, $\mathrm{MeOH}$, trifluoroacetic acid, rt, $8 \mathrm{~h}, 90 \%$; (d) $\mathrm{H}_{2} \mathrm{O}, \mathrm{pH} 7.0,60{ }^{\circ} \mathrm{C}, 5 \mathrm{~d}, 56 \%$. In 7 and 8, $\mathrm{R}_{1}=2,6$-diamino-2,6-di- $N$-(benzyloxycarbonyl)-2,6-dideoxy- $\beta$ L-idose.

in $\mathrm{MeOH} / \mathrm{TFA}$. The resulting crude sulfonate was cyclized at $40{ }^{\circ} \mathrm{C}$ and $\mathrm{pH} 7.0$ in $\mathrm{H}_{2} \mathrm{O}$ to give 3 in $62 \%$ yield.

The cyclization proceeded with an astonishing high regioselectivity considering the number of amino groups present in this neomycin-B derivative (see Figure S1). In fact, compound $\mathbf{3}$ is the only macrocyclic derivative isolated from the reaction mixture. Close inspection of the corresponding molecular model shows that the two amino groups present in unit IV could also participate in the nucleophilic attack to the side chain of III. However, preliminary molecular mechanics calculations suggest that the cyclization involving $\mathrm{NH}_{2}$ at position 2 of unit IV would proceed through a high energy transition state. The preferred cyclization through the $\mathrm{NH}_{2}$ at position 2 of ring I instead of that at position 6 of unit IV can be explained considering the different $\mathrm{p} K_{\mathrm{a}}$ values of these groups (7.4 vs 8.5, respectively). In fact, under the employed experimental conditions ( $\mathrm{pH}$ 7.0), the later amino group is fundamentally in its protonated state.

Compound 6 was readily obtained from 17 by palladiumcatalyzed hydrogenolysis of the $\mathrm{Cbz}$ protecting groups and subsequent reduction of the primary sulfonate under the same conditions using a longer reaction time.

Finally derivatives $\mathbf{4}$ and $\mathbf{5}$ were easily obtained from $\mathbf{1 1}$ as described in the Supporting Information.

NMR Analysis of the Conformationally Locked Aminoglycosides 2-4. Selective 1D-NOE experiments were carried out at $313 \mathrm{~K}$ and $\mathrm{pH} 5.0$ for analogues $\mathbf{2 - 4}$. In addition, ${ }^{3} \boldsymbol{J}$ values were measured for all the sugar units (Table 1). To get an experimentally derived ensemble, MD-tar (molecular dynamics with time-averaged restraints) simulations ${ }^{25}$ were carried out by including all the experimental NOE-derived distances and $J$ data as time-average restraints with the AMBER 5.026 program, as described. ${ }^{16}$

The obtained trajectories were able to quantitatively reproduce all the NMR experimental data. In all cases, the analyses of the $J$ couplings for units I and II unambiguously show that the ${ }^{4} C_{1}$ conformer is the very major one in water $(>98 \%)$. In contrast, for ring IV the ${ }^{1} \mathrm{C}_{4}$ conformer with three axial and two equatorial substituents is the only one experimentally detected. A similar behavior has been reported for the natural antibiotic, ${ }^{16}$ and therefore the cyclization of neomycin-B to give $\mathbf{2}-\mathbf{3}$ does not produce significant distortions in any of the three pyranose rings.

According to the experimental data, derivative $\mathbf{2}$ is extremely rigid. Both $J$ and NOE values (see Table 1 and Figure 1) are consistent with a pure "gt" $\left(\omega_{\mathrm{O}-\mathrm{C} 4-\mathrm{C} 5-\mathrm{O} 5} \approx 60^{\circ}\right)$ orientation for the side chain of unit III and a unique puckering for its furanose ring. In fact, only minor fluctuations around the I/II and III/II glycosidic linkages are compatible with this macrocyclic structure, according to the MD-tar simulations.

A summary of the experimental data employed in the NMR analysis of $\mathbf{3}$ is shown in Figure 2. In this case, a large number of lower bound constraints had to be included in the MD-tar simulations (together with the NOE derived distances and $J$ values) to properly define its structure in solution. As expected, the experimental data indicates the presence of a larger degree of flexibility. Thus, NOEs and $J$ values are consistent with the

(25) Pearlman, D. A. J. Biomol. NMR 1994, 4, 1-16.

(26) Pearlman, D. A.; Case, D. A.; Caldwell, J. W.; Ross, W. S.; Cheatham, T. E.; DeBolt, S.; Ferguson, D.; Siebal, G.; Kollman, P. Comput. Phys. Commun. 1995, 91, 1-41. 


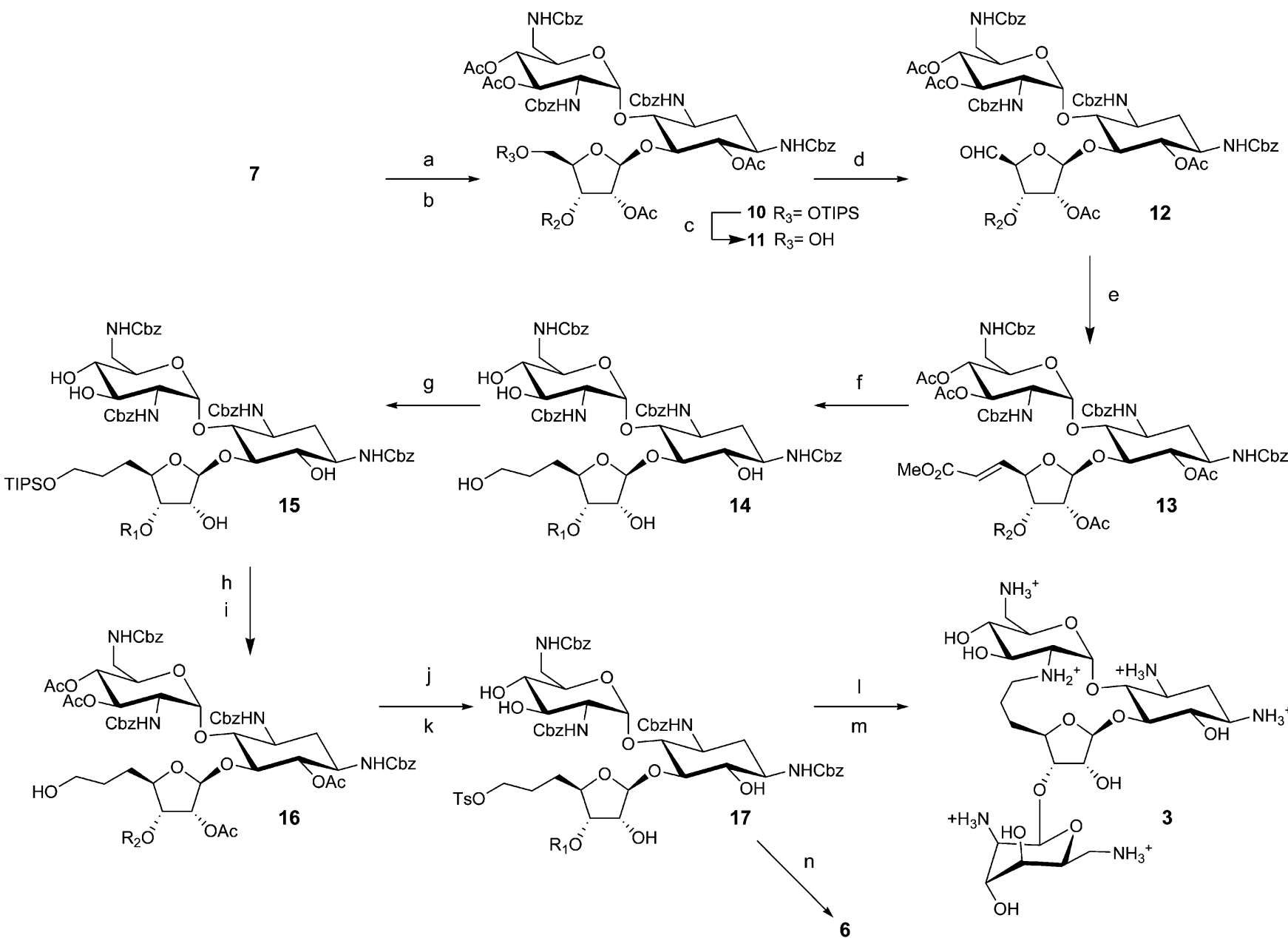

${ }^{a}$ (a) Triisopropylsilyl trifluoromethanesulfonate (TIPSOTf), 2,6-lutidine, THF, rt, 1 h, $80 \%$; (b) $\mathrm{Ac}_{2} \mathrm{O}, \mathrm{Py}, \mathrm{rt}, 5 \mathrm{~h}, \sim 100 \%$; (c) $\mathrm{HF} \cdot \mathrm{Py}, \mathrm{THF}$, rt, 5 h, $90 \%$; (d) Dess-Martin periodinane, $\mathrm{CH}_{2} \mathrm{Cl}_{2}$, rt, $2 \mathrm{~h}$, 79\%; (e) $\mathrm{Ph}_{3} \mathrm{P}=\mathrm{CHCO}_{2} \mathrm{Me}, \mathrm{CH}_{3} \mathrm{CN}$, rt, 3h, 82\%; (f) $\mathrm{NaBH}_{4}$, cat. LiCl, EtOH/THF, rt, 12 h, 89\%; (g) TIPSOTf, 2,6-lutidine, THF, $0{ }^{\circ} \mathrm{C}, 1 \mathrm{~h}, 60 \%$; (h) $\mathrm{Ac}_{2} \mathrm{O}, \mathrm{Py}$, rt, 5h, $\sim 100 \%$; (i) HF•Py, THF, rt, $5 \mathrm{~h}, 79 \%$; (j) $p$-toluenesulfonyl chloride (TsCl), Py, cat. DMAP, rt, 3 h, 79\%; (k) cat. KCN, MeOH/THF 2:1, rt, 10 h, 58\%; (1) $\mathrm{H}_{2}$ (1 atm), $\mathrm{Pd} / \mathrm{C}, \mathrm{MeOH}$, trifluoroacetic acid, rt, $8 \mathrm{~h}, \sim 88 \%$; (m) $\mathrm{H}_{2} \mathrm{O}, \mathrm{pH} 7.0,40{ }^{\circ} \mathrm{C}, 10 \mathrm{~d}, 62 \%$; (n) $\mathrm{H}_{2}$ (1 atm), Pd/C, $\mathrm{MeOH}$, trifluoroacetic acid, rt, $48 \mathrm{~h}, \sim 60 \%$; In 14, 15, and $17 \mathrm{R}_{1}=2$,6-diamino-2,6-di- $N$-(benzyloxycarbonyl)-2,6-dideoxy- $\beta$-L-idose In 10-13 and $16 \mathrm{R}_{2}=3,4$-di- $O$-acetyl-2,6-diamino-2,6-di- $N$-(benzyloxycarbonyl)-2,6-dideoxy- $\beta$-L-idose.

presence of several orientations for the propylidene bridge that links units I and III. For the side chain of ring III, a major $(>80 \%)$ "gt" $\left(\omega_{\mathrm{O}-\mathrm{C} 4-\mathrm{C} 5-\mathrm{C} 6} \approx 60^{\circ}\right)$ and a minor $(<20 \%)$ "gg" $\left(\omega_{\mathrm{O}-\mathrm{C} 4-\mathrm{C} 5-\mathrm{C} 6} \approx-60^{\circ}\right)$ orientation are detected. Moreover, the furanose ring presents two different puckerings characterized by phase angles of $25^{\circ}$ ("North") and $160^{\circ}$ ("South") (for phase angles the Altoona and Sundaralingan ${ }^{27}$ convention is employed) and relative populations of 40:60, respectively. According to the MD-tar trajectories, the macrocyclic structure present in $\mathbf{3}$ is compatible with relatively large fluctuations around the I/II and III/II glycosidic linkages (see Figure 3).

Finally, our combined NMR/MD approach indicates that derivative $\mathbf{4}$ also exhibits a significant degree of flexibility (Figure 4). As previously observed for $\mathbf{3}$, ring III presents two different puckerings characterized by phase angles around $5^{\circ}$ and $170^{\circ}$ and relative populations of $30: 70$, respectively. The polar interaction between $\mathrm{NH}_{2}$ I and the carboxylate present in III (see Figure 4) seems to be compatible with the presence of relatively wide fluctuations around the I/II and III/II glycosidic linkages.

(27) Altona, C.; Sundaralingham, M. J. Am. Chem. Soc. 1972, 94, 8205-8208.
The obtained ensembles of conformers for $\mathbf{2}-\mathbf{4}$ that quantitatively reproduce the experimental data are shown in Figure 5. These ensembles were compared to that obtained for the natural antibiotic 1 in the free (experimentally derived from the NMR data) ${ }^{16}$ and RNA-bound (derived from unrestrained MD simulations of the neomycin-B/A-site complex) states. ${ }^{16}$ As expected, analogues $\mathbf{2}-\mathbf{4}$ are more rigid than $\mathbf{1}$ in the free state. The RMSD for heavy atom superimposition for the ensemble corresponding to 1 in the free state is $2.1 \AA$ changing to $0.4 \AA$ for the bound ligand. The corresponding values for $\mathbf{3}$ and $\mathbf{4}$ are 1.6 A. The conformational restriction imposed by covalently bonding $\mathrm{C5}_{\mathrm{III}}$ to $\mathrm{N}_{2}$ in $\mathbf{2}$ is especially severe with an RMSD value of $0.9 \AA$.

Interestingly, the locked aminoglycosides $\mathbf{2 - 4}$ closely resemble the bioactive conformation of the natural antibiotic. The most representative minimum energy conformations present in solution for $\mathbf{2}$ and $\mathbf{3}$, superimposed on the X-ray structure of paromomycin in complex with A-site RNA, are shown in Figure 6. For 2 , deviations in $\Phi / \Psi$ values with respect to the paromomycin bound structure are less than $11^{\circ}$ and $21^{\circ}$ for the I/II and III/II linkages, respectively. The corresponding devia- 
Table 1. Experimental and Theoretical Distances (above) and Coupling Constant Values (below) Obtained for Compounds 2, 3, and 4 at $\mathrm{pH} 5.0^{\mathrm{a}}$

\begin{tabular}{|c|c|c|c|c|c|c|}
\hline \multirow[b]{2}{*}{$d(\AA \AA)$} & \multicolumn{2}{|c|}{ compound 2} & \multicolumn{2}{|c|}{ compound 3} & \multicolumn{2}{|c|}{ compound 4} \\
\hline & expmt & $\begin{array}{c}\text { MD-tar } \\
(5 \mathrm{~ns})\end{array}$ & expmt & $\begin{array}{l}\text { MD-tar } \\
(80 \mathrm{~ns})\end{array}$ & expmt & $\begin{array}{r}\text { MD-tar } \\
(5 \mathrm{~ns})\end{array}$ \\
\hline $\mathrm{H} 1_{\mathrm{I}}-\mathrm{H} 4_{\text {II }}$ & 2.4 & 2.4 & 2.4 & 2.3 & 2.5 & 2.5 \\
\hline $\mathrm{H} 1_{\mathrm{I}}-\mathrm{H} 5_{\mathrm{II}}$ & & & $>3.3$ & 3.8 & 3.3 & 3.2 \\
\hline $\mathrm{H} 1_{\mathrm{I}}-\mathrm{H} 1_{\mathrm{III}}$ & & & $>3.3$ & 4.5 & 3.9 & 4.0 \\
\hline $\mathrm{H} 1_{\mathrm{I}}-\mathrm{H} 2_{\mathrm{III}}$ & & & $>3.3$ & 3.7 & 3.4 & 3.2 \\
\hline $\mathrm{H} 1_{\mathrm{I}}-\mathrm{H} 3_{\mathrm{III}}$ & & & $>3.3$ & 3.3 & & \\
\hline $\mathrm{H} 1_{\mathrm{I}}-\mathrm{H} 5_{\text {III }} \mathrm{R}$ & 2.4 & 2.3 & $>3.3$ & 5.1 & & \\
\hline $\mathrm{H} 1_{\mathrm{I}}-\mathrm{H} 5_{\mathrm{III}} S$ & & & $>3.3$ & 3.3 & & \\
\hline $\mathrm{H} 1_{\mathrm{I}}-\mathrm{H} 6_{\mathrm{III}} R / S$ & & & $>3.3 />3.3$ & $3.3 / 4.6$ & & \\
\hline $\mathrm{H} 1_{\mathrm{I}}-\mathrm{H} 7_{\text {III }} R / S$ & & & $>3.3 />3.3$ & $3.3 / 3.6$ & & \\
\hline $\mathrm{H} 2_{\mathrm{I}}-\mathrm{H} 5_{\mathrm{III}} R$ & $<2.4$ & 2.4 & & & & \\
\hline $\mathrm{H} 2_{\mathrm{I}}-\mathrm{H} 7_{\mathrm{III}} R$ & & & 2.6 & 2.6 & & \\
\hline $\mathrm{H} 3_{\mathrm{I}}-\mathrm{H} 7_{\mathrm{III}} R / S$ & & & $>3.3 />3.3$ & $3.5 / 3.3$ & & \\
\hline $\mathrm{H} 1_{\text {III }}-\mathrm{H} 5_{\mathrm{II}}$ & 2.6 & 2.6 & 2.2 & 2.3 & 2.5 & 2.5 \\
\hline $\mathrm{H} 1_{\mathrm{III}}-\mathrm{H} 4_{\mathrm{II}}$ & $>3.5$ & 4.5 & $>3.3$ & 4.4 & & \\
\hline $\mathrm{H} 1_{\mathrm{III}}-\mathrm{H} 6_{\mathrm{II}}$ & 3.5 & 3.6 & $>3.3$ & 3.7 & 3.6 & 3.3 \\
\hline $\mathrm{H} 1_{\text {IIII }}-\mathrm{H} 4_{\text {IIII }}$ & 3.6 & 3.7 & 3.1 & 3.0 & 3.5 & 3.3 \\
\hline $\mathrm{H} 2_{I I I}-\mathrm{H} 7_{\text {III }} R / S$ & & & $>3.3 />3.3$ & $3.3 / 4.9$ & & \\
\hline $\mathrm{H} 2_{\mathrm{III}}-\mathrm{H} 6_{\mathrm{II}}$ & & & $>3.3$ & 4.2 & 3.2 & 3.3 \\
\hline $\mathrm{H} 2_{\mathrm{III}}-\mathrm{H} 6_{\mathrm{III}} R / S$ & & & $>3.3 />3.3$ & $4.9 / 3.4$ & & \\
\hline $\mathrm{H} 2_{\mathrm{III}}-\mathrm{H} 5_{\mathrm{III}} R$ & $<2.4$ & 2.2 & & & & \\
\hline $\mathrm{H} 3_{\mathrm{III}}-\mathrm{H} 7_{\mathrm{III}} R / S$ & & & $>3.3 />3.3$ & $3.3 / 4.6$ & & \\
\hline $\mathrm{H} 3_{I I I}-\mathrm{H} 6_{I I I} R / S$ & & & $>3.3 />3.3$ & $4.3 / 3.2$ & & \\
\hline $\mathrm{H} 4_{\mathrm{III}}-\mathrm{H} 6_{\mathrm{III}} R / S$ & & & $>3.3 />3.3$ & $3.2 / 3.8$ & & \\
\hline $\mathrm{H} 1_{\mathrm{IV}}-\mathrm{H} 2_{\mathrm{III}}$ & $>4$ & 4 & & & & \\
\hline $\mathrm{H} 1_{\mathrm{IV}}-\mathrm{H} 3_{\mathrm{III}}$ & 2.5 & 2.6 & 2.5 & 2.3 & 2.4 & 2.5 \\
\hline $\mathrm{H} 1_{\mathrm{IV}}-\mathrm{H} 4_{\mathrm{III}}$ & 3.5 & 3.5 & $>3.3$ & 4.0 & 3.8 & 3.9 \\
\hline$J(\mathrm{~Hz})$ & expmt & $\begin{array}{c}\text { MD-tar } \\
(5 \mathrm{~ns})\end{array}$ & expmt & $\begin{array}{l}\text { MD-tar } \\
(80 \mathrm{~ns})\end{array}$ & expmt & $\begin{array}{c}\text { MD-tar } \\
(5 \mathrm{~ns})\end{array}$ \\
\hline $\mathrm{H} 1_{\mathrm{III}}-\mathrm{H} 2_{\mathrm{III}}$ & 3.9 & 4.5 & 3.5 & 4.1 & 3.9 & 4.0 \\
\hline $\mathrm{H} 2_{I I I}-\mathrm{H} 3_{\text {III }}$ & 4.9 & 4.2 & & & 4.0 & 4.1 \\
\hline $\mathrm{H} 3_{\mathrm{III}}-\mathrm{H} 4_{\mathrm{III}}$ & $<1.0$ & 1.1 & 3.5 & 4.5 & 4.4 & 4.3 \\
\hline $\mathrm{H} 4_{\text {III }}-\mathrm{H} 5_{\text {III }} R$ & 11.6 & 11.0 & $<3.5$ & 4.1 & & \\
\hline $\mathrm{H} 4_{\text {III }}-\mathrm{H} 5_{\text {III }} S$ & 4.0 & 4.7 & 9.5 & 8.8 & & \\
\hline $\mathrm{H}_{\text {III }} R-\mathrm{H} 6_{\text {III }} R$ & & & 3.0 & 3.4 & & \\
\hline $\mathrm{H}_{\text {III }} R-\mathrm{H} 6_{\text {III }} S$ & & & 8.5 & 7.9 & & \\
\hline $\mathrm{H}^{\mathrm{IIII}} S-\mathrm{H} 6_{\mathrm{III}} R$ & & & 7.0 & 7.2 & & \\
\hline
\end{tabular}

${ }^{a}$ Molecular dynamic simulations with time-averaged restraints (MDtar) for compounds $\mathbf{2}$ and $\mathbf{4}$ were carried out using explicit solvent, counterions, periodic boundary conditions (PBC), and Ewald sums for the treatment of electrostatic interactions. For compound $\mathbf{3}$, in vacuo $80 \mathrm{~ns}$ MDtar trajectories were collected (see the Materials and Methods). The stereochemistry of the protons involved in the distance constraints is indicated when appropriate.

tions for 3 are larger $\left(15^{\circ}\right.$ and $\left.45^{\circ}\right)$. However, the global shape of the molecule is very similar to that observed for paromomycin in the RNA-bound state, as shown by the low RMSD values for heavy atom superimposition (see Figure 6).

Previous studies have shown that neomycin-B in solution is characterized by a remarkable flexibility, with different conformations around the three glycosidic linkages and two different conformational populations for the unit III furanose ring (with phase angles $\sim 20^{\circ}$ and $\sim 160^{\circ}$ and populations of $60-70 \%$ and $30-40 \%$, respectively) in fast exchange. ${ }^{16}$ On the other hand, MD simulations of neomycin-B complexed to ribosomal A-site RNA suggest that its flexibility is severely reduced upon binding and only one of the furanose conformations is selected by the RNA receptor. Interestingly, in analogue $\mathbf{2}$, the unit III furanose is locked in a very similar conformation to that present in the A-site/paromomycin complex, with an almost identical orientation of the key polar groups, $\mathrm{O} 2$ and $\mathrm{O} 3$ (Figure 6).

In conclusion, according to our structural analysis, derivatives 2-4 satisfy the basic requirements for an optimal conforma- tionally constrained derivative; they are all more rigid than the natural antibiotic neomycin-B and closely resemble its bioactive, RNA-bound conformation.

Fluorescence-Based Analysis of the Interaction between Aminoglycosides 1-6 and the Ribosomal Decoding Site. As a next step, the binding properties of compounds $\mathbf{1 - 4}$ to ribosomal RNA were analyzed. It is known that, for natural paromomycin, $\mathrm{OH}_{\mathrm{III}}$ is involved in RNA recognition. ${ }^{5,6} \mathrm{Cy}$ clization of neomycin-B to give $\mathbf{2}$ and $\mathbf{3}$ requires the removal of this $\mathrm{OH}$ group. To isolate the effect of rigidification on the aminoglycoside-RNA interaction, the binding properties of the deoxyderivatives $\mathbf{5}$ and $\mathbf{6}$ were also tested. The fluorescencebased approach, developed independently by Pilch ${ }^{28}$ and Hermann, ${ }^{29}$ was employed. This methodology makes use of a modified 27-mer RNA fragment (A-site(2AP)) including the A-site sequence and the fluorescent base analogue 2-aminopurine (2AP) replacing A1492 (Figure 7a). It is well established that major groove binding of aminoglycosides to the A-site induces a significant conformational change in the RNA so that the adenine residues at positions 1492 and 1493 are displaced from the helical stack toward the minor groove. ${ }^{5-7}$ As the fluorescence of $2 \mathrm{AP}$ is modulated by hydrophobic stacking interactions, the employed RNA fragment (shown in Figure 7a) provides an adequate means for monitoring and quantifying the destacking of A1492 that accompanies complex formation.

It has been shown that paromomycin binding to the A-site(2AP) induces a marked increase in the fluorescence intensity at 369 $\mathrm{nm}$. These changes were monitored as a function of the [drug]/ [RNA] ratio in titration experiments, to derive Kd values. Some typical binding curves are shown in Figure $7 \mathrm{~b}$. The affinity constants measured for compounds $\mathbf{1 - 6}$ are shown in Figure 8. According to our titration experiments, natural neomycin-B binds to the A-site with a $\mathrm{Kd}$ value of $0.07 \mu \mathrm{M}$ in $100 \mathrm{mM}$ $\mathrm{NaCl}, 10 \mathrm{mM}$ phosphate and $\mathrm{pH}$ 7.6. This result is in agreement with previously reported values obtained by other methods under comparable experimental conditions. ${ }^{30}$

The maximum fluorescence increases observed for the neomycin-B derivatives $(\mathbf{2}, \mathbf{3}, \mathbf{5}$, and $\mathbf{6})$ are similar to that detected for the parent compound (1), suggesting the presence of similar binding modes. The corresponding $\mathrm{Kd}$ values are shown in Figure 8a. It can be observed that deoxy derivatives 5 and 6 present a 10-fold reduction in affinity with respect to the natural compound $\mathbf{1}$. This result is not unexpected as $\mathrm{OH} 5_{\mathrm{III}}$ is involved in a hydrogen bond with G1491 in the paromomycin/ A-site complex. Therefore, the $\Delta G$ contribution of this hydrogen bond can be estimated as $\sim 1.3 \mathrm{kcal} / \mathrm{mol}$. The observed affinities for the macrocyclic derivatives $\mathbf{2}$ and $\mathbf{3}$ are in the same range of those observed for the corresponding open deoxyanalogues $\mathbf{5}$ and $\mathbf{6}$, respectively. According to these data, under the employed experimental conditions, the $\Delta G$ contribution resulting from the conformational restriction is almost negligible. ${ }^{31,32}$

(28) Kaul, M.; Barbieri, C. M.; Pilch, D. S. J. Am. Chem. Soc. 2004, 126, $3447-$ 3453.

(29) Shandrick, S.; Zhao, Q.; Han, Q.; Ayida, B. K.; Takahashi, M.; Winters, G. C.; Simonsen, K. B.; Vourloumis, D.; Hermann, T. Angew. Chem., Int. Ed. 2004, 43, 3177-3182.

(30) (a) Wang, Y.; Hamasaki, K.; Rando, R. R. Biochemistry 1997, 36, $768-$ 779. (b) Ryu, D. H.; Litovchick, A.; Rando, R. R. Biochemistry 2002, 41 , 10499-10509. (c) Fourmy, D.; Recht, M. I.; Puglisi, J. D. J. Mol. Biol. 1998, 277, 347-362. 
a)
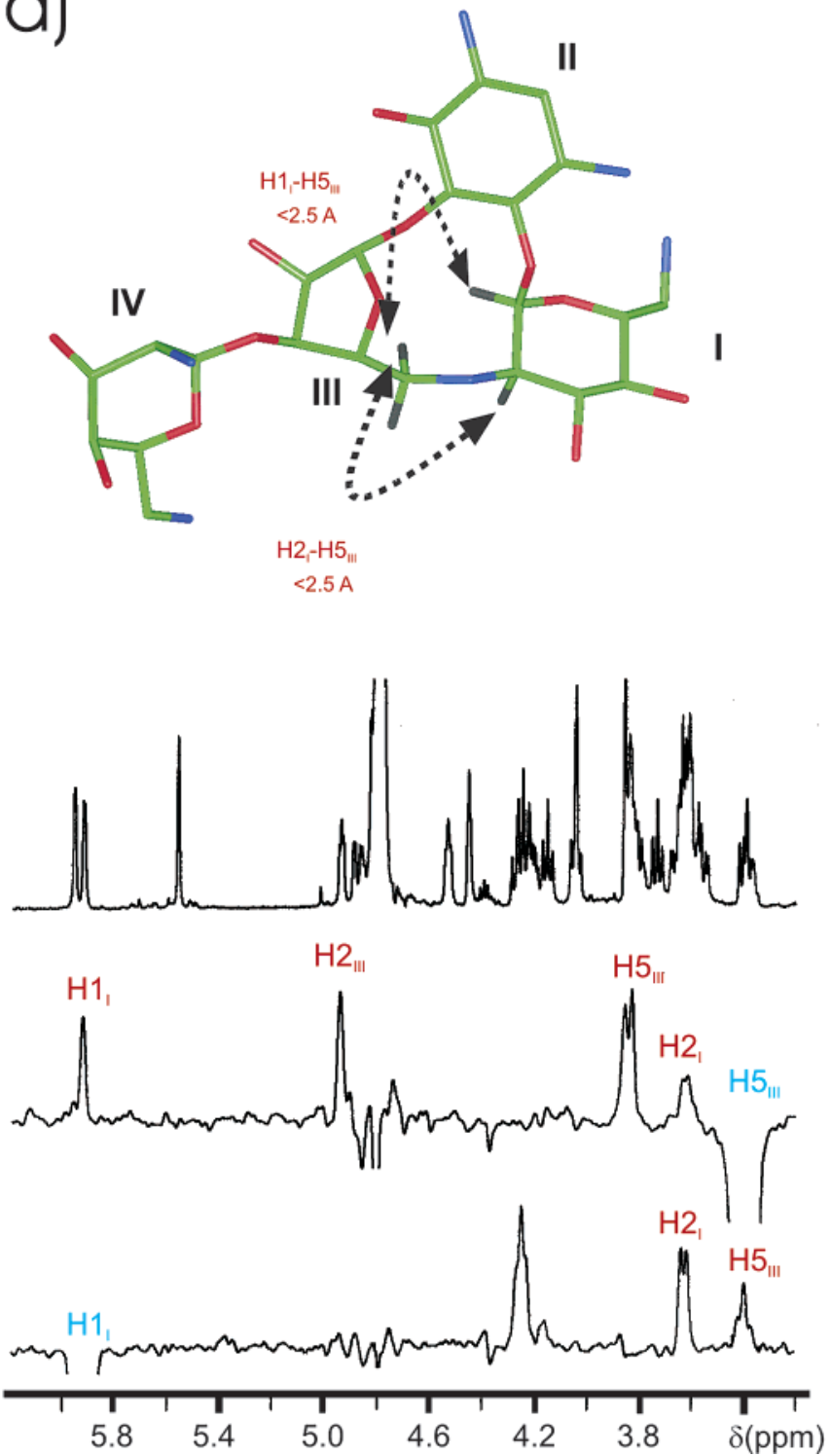

b)
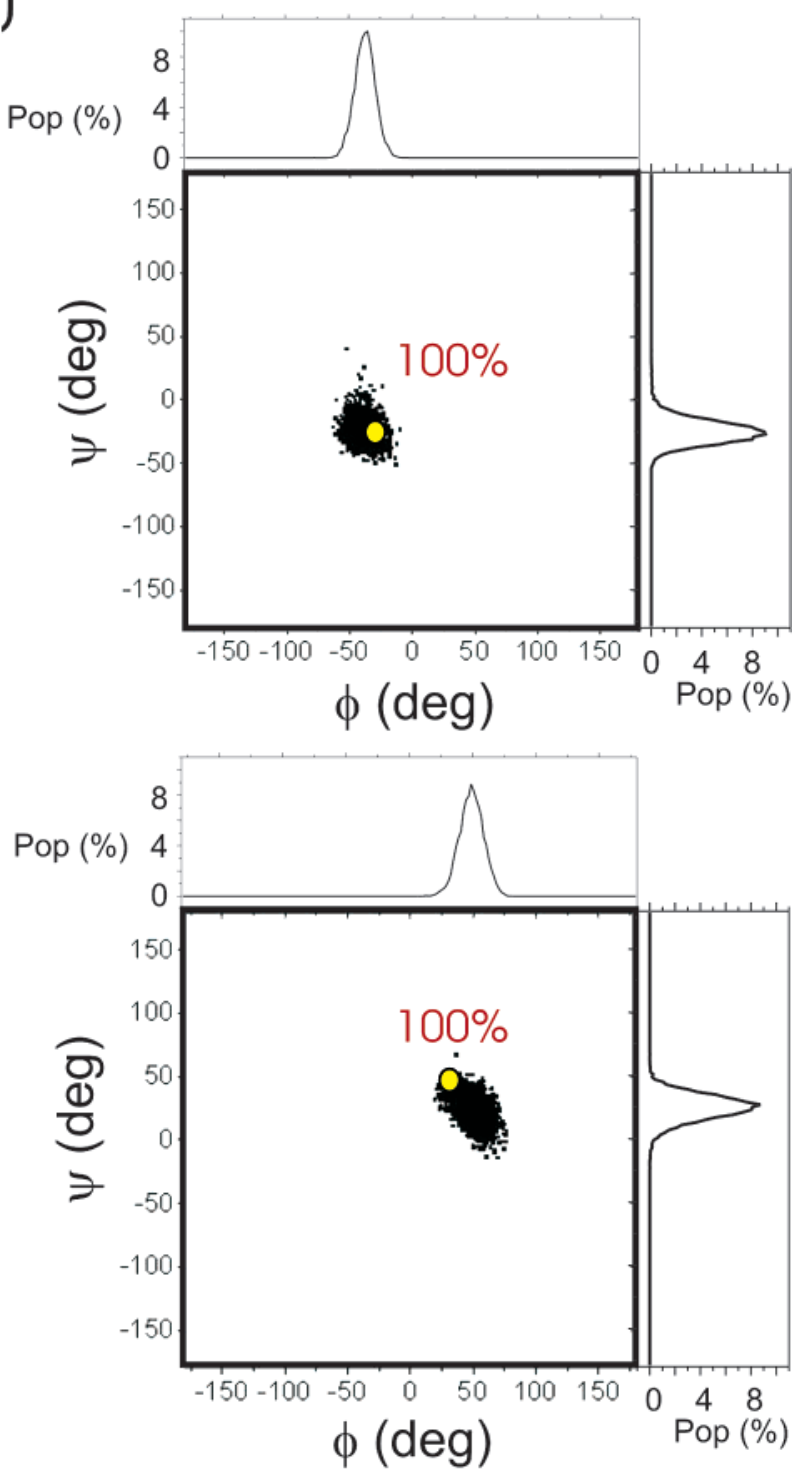

Figure 1. (a) Selective 1D NOE experiments with the 1D-DPFGSE NOE pulse sequence, corresponding to the inversion of $\mathrm{H} 5_{\mathrm{III}}$ and $\mathrm{H} 1_{\mathrm{I}}$ in compound 2. Key NOEs probing the spatial proximity of units I and III are highlighted in the upper part of the figure. The numbering employed for the different sugar units is also indicated. (b) MD-tar $\Phi / \Psi$ distributions obtained for the I/II (upper panel) and III/II (lower panel) glycosidic linkages. The values corresponding to the paromomycin-RNA bound form are indicated with a yellow dot.

Conformational freedom has been shown to play a key role in the recognition of ligands by receptors. ${ }^{33}$ Several attempts have been made to exploit the decrease of conformational entropy of a particular ligand by either locking or biasing conformations toward the bioactive one. In some cases, the

(31) While this manuscript was in preparation, Tor and co-workers reported the interaction of both the locked derivative $\mathbf{2}$ and the corresponding paromomycin analogue with the same labeled A-site RNA fragment Although the buffer conditions employed for the fluorescence measurements differ from ours, the reported decrease in affinity for the locked derivatives is 22-14-fold with respect to the parent aminoglycosides, in agreement with our results; Blount, K. F.; Zhao, F.; Hermann, T.; Tor, Y. J. Am. Chem. Soc. 2005, 127 (27), 9818-9829.

(32) The 3D structure of derivative $\mathbf{2}$ in complex with the A-site, reported by Hermann and col while this manuscript was under revision, shows that rings III and IV present a slightly different orientation in the RNA major groove from that observed for natural Neomycin-B. As a result, the number of ligand-RNA contacts established by these two units is reduced. Zhao, F.; Zhao, Q.; Blount, K. F.; Han, Q.; Tor, Y.; Hermann, T. Angew. Chem., Int. Ed. 2005, 44, 5329-5334.

(33) (a) Williams, D. H.; Searle, M. S.; Mackay, J. P.; Gerhard, U.; Maplestone, R. A. Proc. Natl. Acad. Sci. U.S.A.. 1993, 90, 1172-1178. (b) Calderone, C. T.; Williams, D. H. J. Am. Chem. Soc. 2001, 123, 6262-6267. constrained derivatives presented significantly larger affinities for the receptor than the natural ligand. ${ }^{34}$ In contrast, reported results for carbohydrate-protein interactions range from modest $\Delta G$ benefits $(<0.5 \mathrm{kcal} / \mathrm{mol})^{35}$ to small penalties $\mathrm{s}^{35,36}(<0.3 \mathrm{kcal} /$ $\mathrm{mol})$. In these cases, the small effect of the conformational constraint on the global $\Delta G$ has been attributed to an entropyenthalpy compensation phenomenona. ${ }^{36}$ Our results indicate that despite the different chemical nature of both the ligand and the receptor, aminoglycoside-RNA interactions exhibit a similar behavior to those previously observed in the recognition of neutral carbohydrates by proteins. Especially striking is the lack

(34) (a) Choi, Y.; Moon, H. R.; Yoshimura, Y.; Marquez, V. E. Nucleoside Nucleotide Nucleic Acids 2003, 22, 547-557. (b) Kim, H. S.; Ohno, M.; Xu, B.; Kim, H. O.; Choi, Y.; Ji, X. D.; Maddileti, S.; Marquez, V. E.; Harden, T. K.; Jacobson, K. A. J. Med. Chem. 2003, 46, 4974-4987.

(35) Navarre, N.; Amiot, N.; van Oijen, A. H.; Imberty, A.; Poveda, A.; JiménezBarbero, J.; Nutley, M. A.; Boons, G. J. Chem. Eur. J. 1999, 5, $2281-$ 2294

(36) Bundle, D. R.; Alibés, R.; Nilar, S.; Otter, A.; Warwas, M.; Zhang, P. J. Am. Chem. Soc. 1998, 120, 5317-5318. 
a)

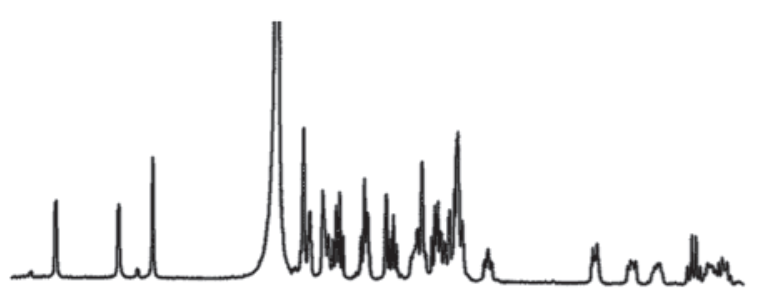

b)

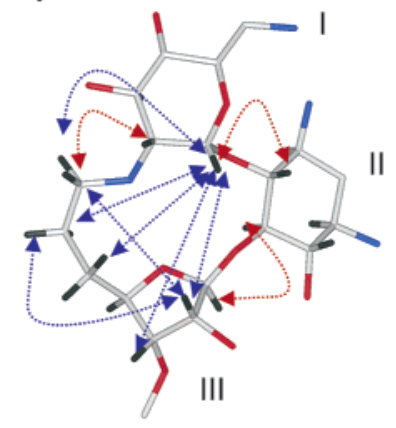

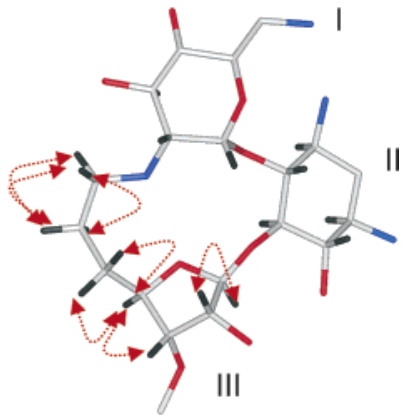

$\mathrm{H} 1_{\mathrm{IV}}$
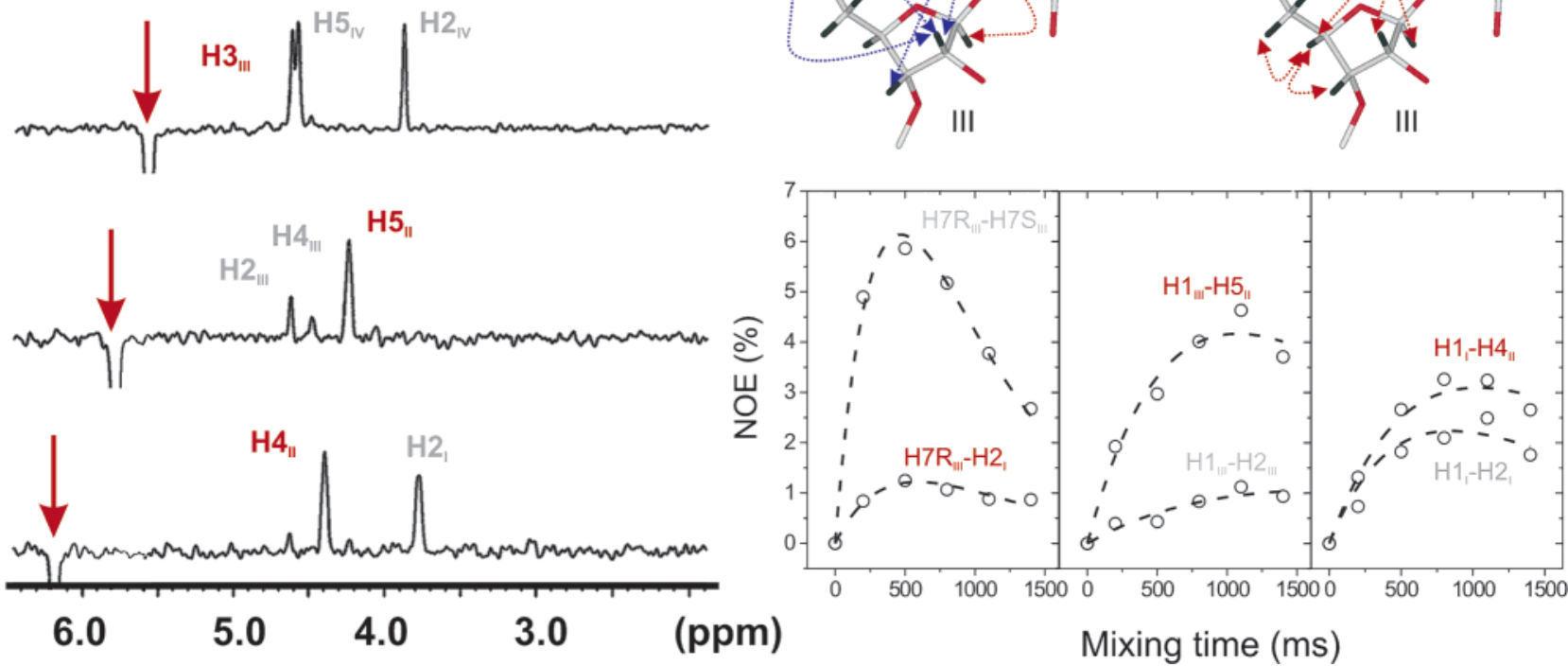

Figure 2. (a) Selective 1D NOE experiments with the 1D-DPFGSE NOE pulse sequence, corresponding to the inversion of the anomeric protons in compound 3. (b) Upper panel: Schematic representation of some of the experimental information employed in the structural analysis of $\mathbf{3}$. The upper left panel shows the observed NOEs as red arrows and those not observed as blue arrows. The upper right panel shows the structurally relevant experimental $J$ couplings measured for 3. The ring IV is omitted for simplicity. Lower panel: some representative NOE buildup curves. NOEs corresponding to known fixed distances, employed as references, are labeled in gray. NOEs corresponding to unknown distances are labeled in red.

of effect that preorganization of the unit III furanose has on the binding strength. Close inspection of molecular models shows that the global shape of the antibiotic is extremely dependent on the precise puckering of this ring. In fact, the specific drugRNA contacts observed in the paromomycin-RNA complex, ${ }^{5,6}$ involving units III and IV and presumably required for tight binding, are only feasible when the furanose adopts a puckering in the "South" region of the pseudorotational path, which is the minor one in the free state. Nevertheless, the original NMR studies by Puglisi and co-workers ${ }^{7}$ showed that, for paromomycin, these rings are dynamic in the ribosome-bound state, and therefore the contacts observed in the crystal structure of the complex might be transient. In addition, the Westhof and Hanessian groups have recently described, for a paromomycin derivative, a new binding mode to the A-site, for which the ribose ring (unit III) is recognized by the RNA receptor in a C2-endo conformation. ${ }^{37}$

Finally, for compound 4, the maximum increase in fluorescence observed upon complex formation is less than half the value observed for neomycin-B, suggesting a smaller structural change in the receptor upon complex formation. It is known that, in the paromomycin-A-site complex, $\mathrm{OH} 5_{\mathrm{III}}$ is located in a strongly electronegative region of the RNA binding pocket. Probably, the substitution of this $\mathrm{OH}$ group by a negatively charged carboxylate precludes a deep penetration of the ligand in the major groove. However, despite this modification, the observed affinity for $\mathbf{4}$ is in the micromolar range.

(37) Francois, B.; Szychowski, J.; Adhikari, S. S.; Pachamuthu, K.; Swayze, E. E.; Griffey, R. H.; Migawa, M. T.; Westhof, E.; Hanessian, S. Angew. Chem., Int. Ed. 2004, 43, 6735-6738.
Effect of the Conformational Constraint on the Antibiotic Activity. The biological activity of the locked neomycin-B derivatives 2-4 was tested against E. coli (see Table 2). For derivative $\mathbf{2}$, a more extensive testing was performed employing both Gram + and Gram - bacteria. Despite the observed decrease in activity with respect to the natural compound $\mathbf{1}$ (3-20-fold depending on the bacteria and the compound), derivatives $\mathbf{2}$ and 3 are still significantly active (with MIC values in the 2.5-20 $\mu \mathrm{g} / \mathrm{mL}$ range). In contrast, derivative 4 showed a poor antibiotic activity. This suggests that $\mathbf{4}$ is adversely affected by other factors such as a different binding mode (as suggested by fluorescence experiments above), different kinetics for crossing the bacterial membrane, digestion or modification by bacterial enzymes, etc. With respect to $\mathbf{2}$ and $\mathbf{3}$, the obtained results show a good correlation with the binding affinities previously measured for ribosomal RNA and indicate that these locked derivatives might potentially be employed as antibiotics. Therefore, the inactivation of these analogues by aminoglycoside modifying enzymes was tested.

Effect of the Conformational Constraint on Aminoglycoside Inactivation by Bacterial Defense Proteins. To analyze the effect that conformational restriction has on the antibiotic enzymatic inactivation, three different enzymes were chosen as model systems: Staphylococcus aureus ANT(4'), Mycobacterium tuberculosis AAC(2'), and Enterococcus faecalis $\mathrm{APH}\left(3^{\prime}\right)$. These proteins are representative of the three main families of enzymes that modify aminoglycosides: adenyltransferases, acyltransferases, and phosphotransferases. In addition, there is high-resolution X-ray structural information available 
a)

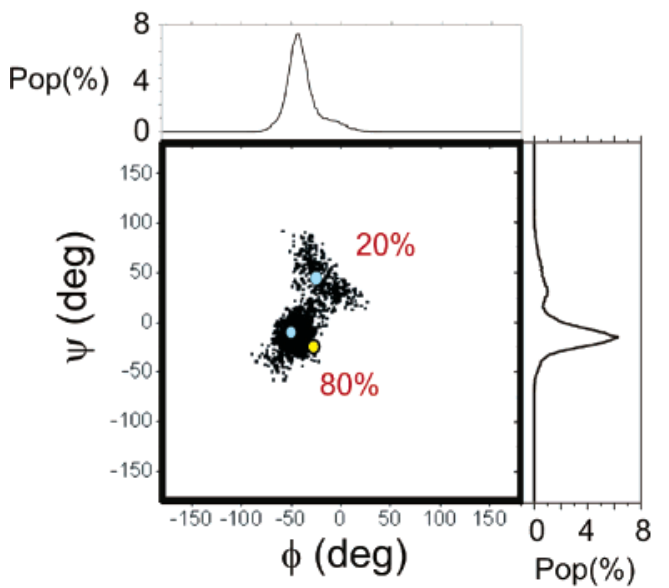

b)

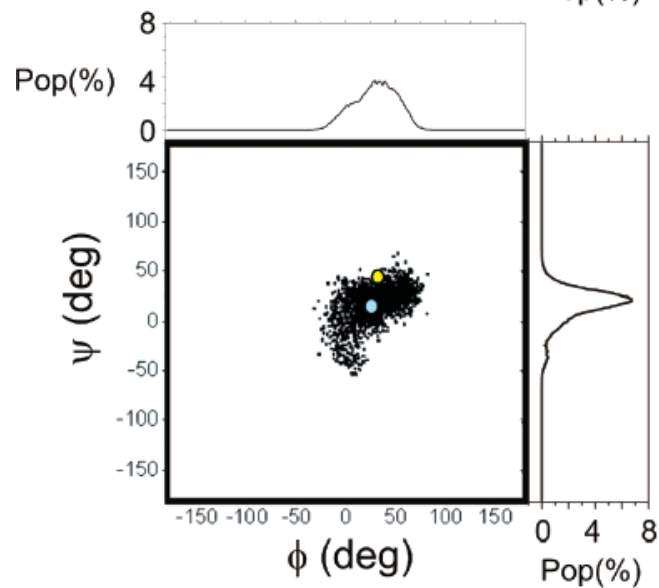

Ribose (III) puckering

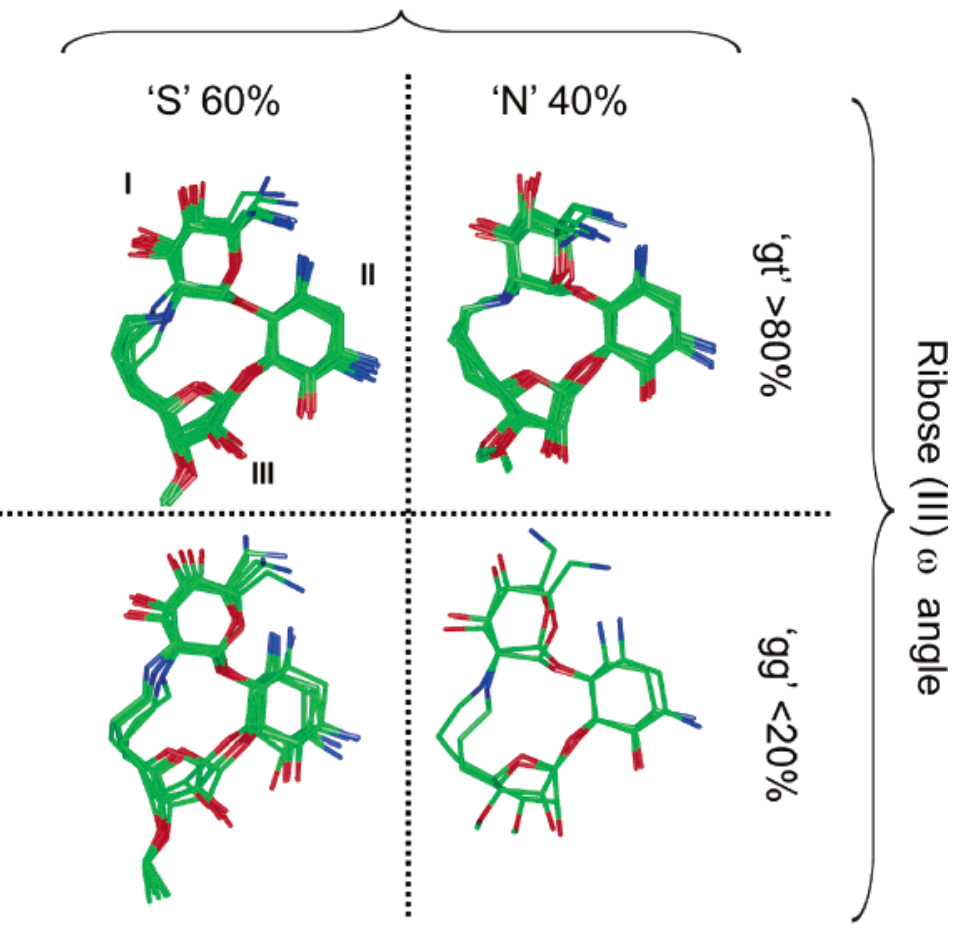

Figure 3. (a) MD-tar $\Phi / \Psi$ distributions obtained for the I/II (upper panel) and III/II (lower panel) glycosidic linkages in compound 3. Minimum energy geometries are indicated with a cyan dot. The $\Phi / \Psi$ values observed for the ligand in the paromomycin-RNA complex are indicated with a yellow dot. (b) Representation of the major conformational populations detected in solution for $\mathbf{3}$. Unit IV is omitted for simplicity.

for the three enzymes in complex with several antibiotics. Analysis of these data permits the deduction of either minor (as in $\mathrm{APH}\left(3^{\prime}\right)$ ) or major (as in $\mathrm{ANT}\left(4^{\prime}\right)$ or $\mathrm{AAC}\left(2^{\prime}\right)$ ) conformational differences, for the aminoglycoside, in the proteinbound state with respect to the RNA-bound state (see Scheme 1). ${ }^{15,17,19}$

Staphylococcus aureus ANT(4') catalyzes the transfer of one adenyl group from ATP to position O-4 (see Scheme 1) of ring I. This transfer leads to a sharp decrease in the drug affinity for its target RNA. The 3D structure of ANT(4') complexed to kanamycin has been determined by using X-ray. ${ }^{15}$ In addition, the structures of related analogues, such as gentamycin, tobramycin, and paromomycin bound to the target ribosomal RNA have also been determined recently. ${ }^{5,6}$ Interestingly, the oligosaccharide conformation recognized by the RNA and by the enzyme is remarkably different, as previously mentioned (see Scheme 1). If it is assumed that some degree of conformational distortion at the I /II fragment is in fact required for enzymatic activity, the conformational restriction introduced in derivatives $\mathbf{2}$ and $\mathbf{3}$ might provide a certain degree of protection against the enzymatic inactivation of the antibiotic.

To test this hypothesis, enzymatic reactions were monitored in NMR tubes. ATP $(100 \mu \mathrm{M}-3 \mathrm{mM})$ and the aminoglycosides $(100 \mu \mathrm{M}-1.5 \mathrm{mM})$ were dissolved in phosphate buffer $(10 \mathrm{mM}$ phosphate, 2.5-5.0 $\mathrm{mM} \mathrm{MgCl}$, $\mathrm{pH}$ 7.0). After addition of the enzyme $(0.2-1.0 \mu \mathrm{M})$, the evolution of the reaction mixture at
$310 \mathrm{~K}$ was monitored by 1D NMR, and the final products were characterized by 2D NMR and MALDI-TOF MS. As shown in Figure 9, at $100 \mu \mathrm{M}$ neomycin-B, $100 \mu \mathrm{M}$ ATP, $2.5 \mathrm{mM} \mathrm{MgCl}_{2}$, and $0.2 \mu \mathrm{M}$ ANT(4'), the adenylation reaction is completed within $22 \mathrm{~min}$. NMR analysis permitted us to confirm that ANT(4') selectively modifies OH4 I. In fact, if only 1 equiv of ATP is employed, this is the only product detected. Interestingly, if 2 ATP equiv are used, nonselective secondary adenylations are detected but at much longer reaction times. For example, at $3 \mathrm{mM}$ ATP, $1.5 \mathrm{mM}$ neomycin-B, $5 \mathrm{mM} \mathrm{MgCl}_{2}$ (pH 7.0, 310 $\mathrm{K})$, and $1 \mu \mathrm{M} \mathrm{ANT}\left(4^{\prime}\right)$, the primary adenylation is completed in $2 \mathrm{~min}$. In contrast, the enzyme requires more than $12 \mathrm{~h}$ to consume the second ATP equivalent, once the primary adenylation is completed. The presence of diadenylated neomycin-B derivatives were confirmed by MALDI-TOF.

For the rigid analogue 2 , at $100 \mu \mathrm{M}$ aminoglycoside, 100 $\mu \mathrm{M}$ ATP, $2.5 \mathrm{mM} \mathrm{MgCl}_{2}$, and $0.2 \mu \mathrm{M}$ ANT(4'), no reaction was detected even $24 \mathrm{~h}$ after enzyme addition (see Figure 9). At larger ANT(4') concentrations (up to $1 \mu \mathrm{M}$ ANT(4')), slow, nonselective adenylation processes (similar to those described above for 1) were observed. In contrast, the related deoxy derivative $\mathbf{5}$ reacted smoothly to give the monoadenylated compound within a few minutes, which demonstrates that the behavior exhibited by $\mathbf{2}$ has its origin in the extra rigidity of the antibiotic and that it is not related to the absence of $\mathrm{OH} 5_{\text {III. }}$. Therefore, the simple modification leading to conformationally 
a)
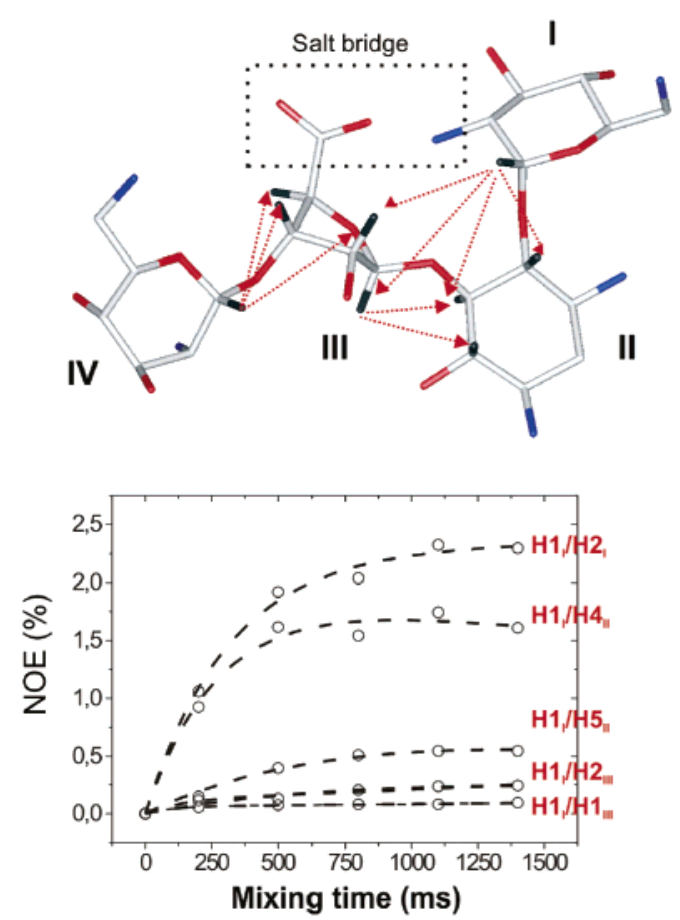

b)
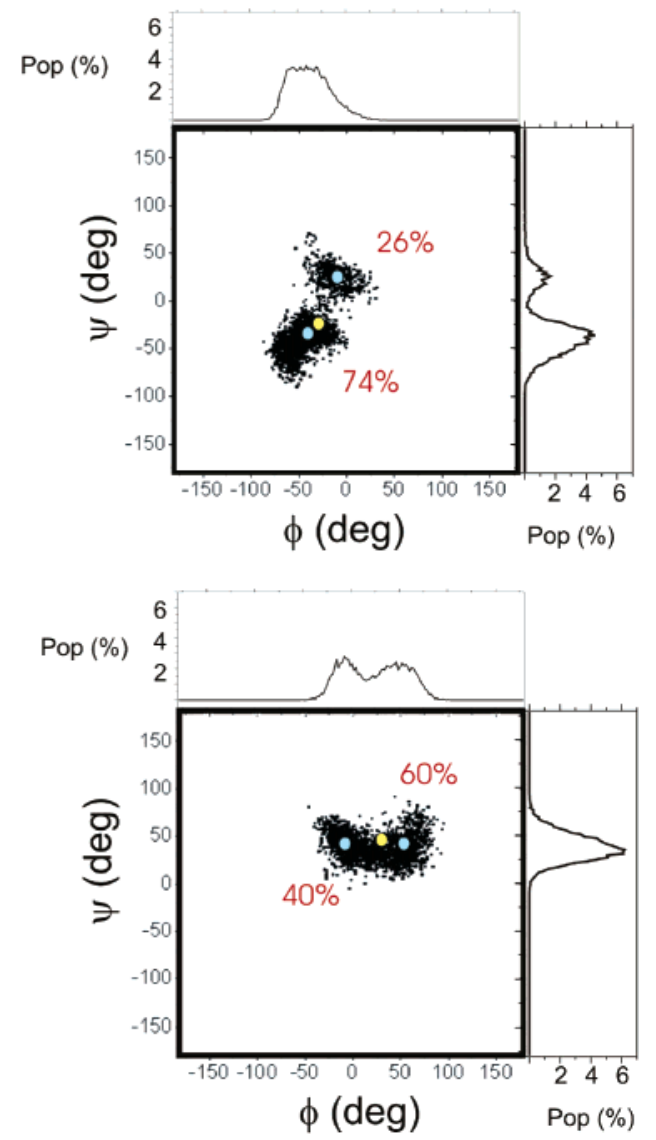

Figure 4. (a) Upper panel: Schematic representation of some of the observed NOEs employed in the structural analysis of 4 . The salt bridge interaction between units III and I is highlighted with a dotted box. Lower panel: Representative NOE build-up curves. (b) MD-tar $\Phi / \Psi$ distributions obtained for the I/II (upper) and III/II (lower) glycosidic linkages. Minimum energy geometries are indicated with a cyan dot. The $\Phi / \Psi$ values corresponding to the paromomycin-RNA bound form are indicated with a yellow dot.

1 (free)

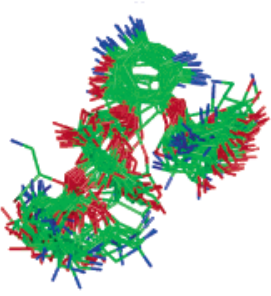

RMSD:

2.1

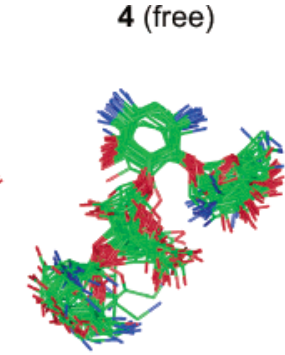

1.6
3 (free)

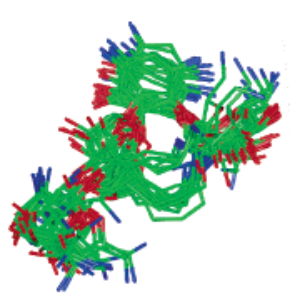

1.6

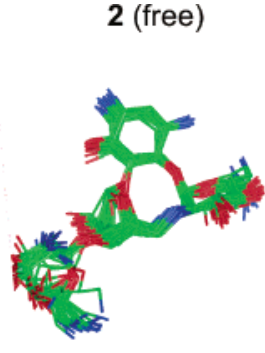

0.9
1 (bound)

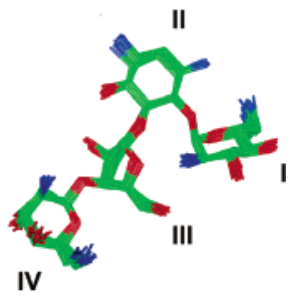

0.4

Figure 5. MD-tar ensembles of conformers for $\mathbf{2 - 4}$. The experimental ensemble corresponding to $\mathbf{1}$ in the free state (left) and that obtained from MD simulations of the neomycin-RNA complex ${ }^{16}$ (right) are shown for comparison. RMSDs (A) for heavy atom superimposition are given below. The numbering employed for the different sugar units is shown on the right.

restricted 2 provides an effective protection against aminoglycoside inactivation by $S$. aureus ANT(4').

Surprisingly, the locked analogue $\mathbf{3}$ exhibited a similar behavior to that observed for the natural antibiotic, neomycinB. Indeed, the specific activities of ANT(4') for aminoglycosides $\mathbf{1}$ and $\mathbf{3}$ are almost identical (see Figure 9). According to these data, it seems that ANT(4') is able to recognize and inactivate aminoglycoside conformations different from the anti- $\Psi$ geometry observed in the enzyme-kanamycin complex ${ }^{15}$ by X-ray methods. In fact, this conformation is not accessible for derivative 3. In any case, these results prove that some degree of conformational flexibility in the ligand is critical for enzymatic activity. For ANT(4') a strong conformational restriction (as present in 2) prevents the antibiotic enzymatic adenylation, although the limited flexibility present in $\mathbf{3}$ restores the enzymatic activity.

In vivo activities of neomycin-B (1) and mimic $\mathbf{2}$ were tested employing the bacteria E. coli DH5 $\alpha$ (pBBR1MCS-2), which expresses the resistance enzyme ANT(4'). As expected, the MIC value for the natural antibiotic is significantly increased (from 3 to $60 \mu \mathrm{g} / \mathrm{mL}$ ). In contrast, the cyclic derivative 2 maintains the same activity observed for the nonresistant bacteria $(20 \mu \mathrm{g} /$ $\mathrm{mL})$. In conclusion, this simple modification leading to the conformationally restricted $\mathbf{2}$ provides an effective protection 


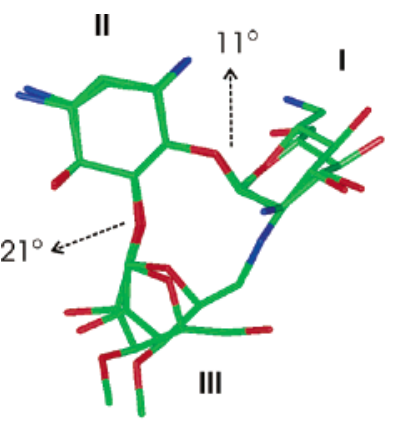

RMSD: 0.5

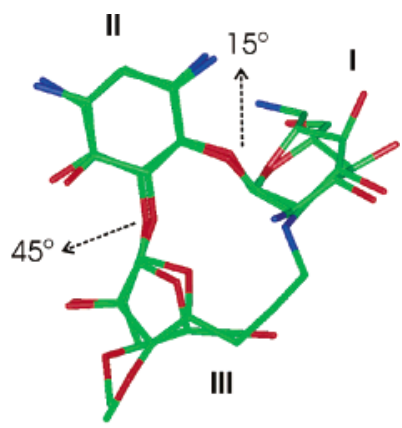

RMSD: 0.7
Figure 6. Structures representative of the main conformational families present in solution for neomycin-B derivatives $\mathbf{2}$ (left) and $\mathbf{3}$ (right) superimposed on the X-ray structure of paromomycin in the complex with ribosomal RNA, according to X-ray data. The maximum $\Phi / \Psi$ deviations (for each glycosidic linkage) and RMSD ( $\AA$ ) values for heavy atom superimpositions are shown. Unit IV is omitted for simplicity.

against aminoglycoside inactivation by $S$. aureus ANT(4'), both in vivo and in vitro, while maintaining a significant antibiotic activity.

Mycobacterium tuberculosis AAC $\left(2^{\prime}\right)$ catalyzes the transfer of one acetyl group from Acetyl CoA to position N-2 (see Scheme 1) of the ring I. The 3D structure of AAC $\left(2^{\prime}\right)$ complexed to ribostamycin has been recently determined by X-ray. ${ }^{17} \mathrm{As}$ previously mentioned, the oligosaccharide conformations bound by the RNA and by the enzyme are remarkably different (see Scheme 1). Interestingly, the recognition of a high energy conformation of the antibiotic seems essential for the enzymatic activity. Thus, by forcing an anti- $\Psi$ geometry around the III/II linkage, the protein increases the accessibility of the reacting $\mathrm{NH} 2$ I group which, otherwise, would be hydrogen-bonded to the nonvicinal unit III in the low energy syn- $\Psi$ minimum. According to the conformational analysis described above, for cyclic derivatives $\mathbf{2}$ and $\mathbf{3}$, this conformational change is no longer possible. Therefore, the geometrical restriction introduced in these derivatives is expected to fully protect the antibiotics from the enzymatic acetylation. To test this hypothesis, enzymatic reactions were performed in NMR tubes employing similar conditions as those previously described for ANT(4') (see Materials and Methods). As shown in Figure 10, at 100 $\mu \mathrm{M}$ neomycin-B, $100 \mu \mathrm{M}$ AcCoA, $2.5 \mathrm{mM} \mathrm{MgCl}_{2}$, and $0.2 \mu \mathrm{M}$ $\mathrm{AAC}\left(2^{\prime}\right)$, the acetylation reaction is completed within $1 \mathrm{~h}$. A similar behavior was observed for the deoxy derivatives $\mathbf{5}$ and 6. In contrast, no reaction was observed for the locked aminoglycosides $\mathbf{2}$ and 3, even after $24 \mathrm{~h}$ and higher enzyme
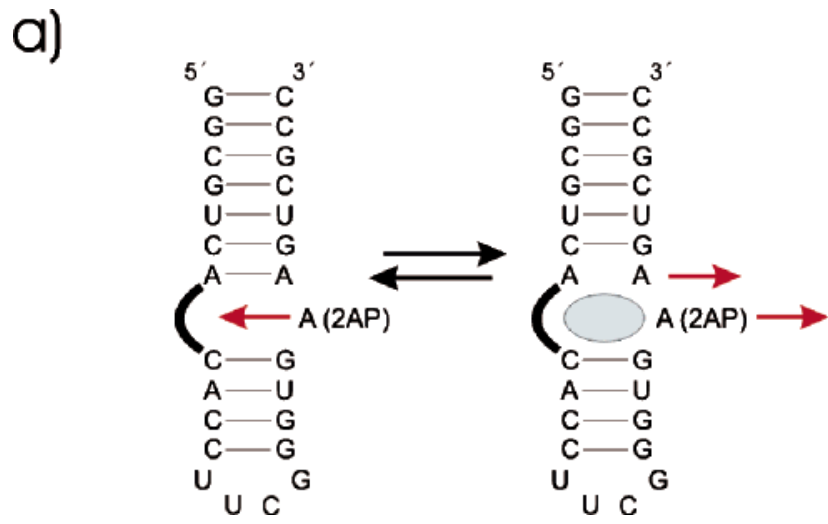

Table 2. Experimental MIC Values ( $\mu \mathrm{g} / \mathrm{mL})$ Measured for Neomycin-B and Its Conformationally Constrained Analogues 2-4

\begin{tabular}{llrcc}
\hline & \multicolumn{4}{c}{ MICs $(\mu \mathrm{g} / \mathrm{mL})$} \\
\cline { 2 - 5 } & \multicolumn{1}{c}{$\mathbf{1}$} & $\mathbf{2}$ & $\mathbf{3}$ & $\mathbf{4}$ \\
\hline E. coli $($ DH5 $\alpha)$ & 3 & 20 & 9 & $>100$ \\
E. coli $($ BL21) & 0.50 & 10 & 2.5 & \\
S. epidermis & 2 & 10 & & \\
Bacillus cereus & 1 & 5 & & \\
Alcaligenes faecalis & 1 & 20 & & \\
& & & & \\
\hline
\end{tabular}

concentrations $(0.2-20 \mu \mathrm{M})$. Therefore, the conformational constraint introduced in $\mathbf{2}$ and $\mathbf{3}$ provides complete protection against aminoglycoside modification by $\mathrm{AAC}\left(2^{\prime}\right)$.

The in vivo activities of neomycin-B (1) and mimic $\mathbf{3}$ were tested employing the bacteria $E$. coli BL21(DE3)(pET23a$\left.\mathrm{AAC}\left(2^{\prime}\right)\right)$, which expresses the resistance enzyme AAC $\left(2^{\prime}\right)$. The MIC values measured for $\mathbf{1}$ and 3 were 2 and $2.5 \mu \mathrm{g} / \mathrm{mL}$, respectively. As expected, $\mathbf{3}$ is not affected by the expression of AAC(2'), and this locked aminoglycoside exhibits a good antibiotic activity. However, under the employed experimental conditions, the AAC $\left(2^{\prime}\right)$ enzymatic activity seems to have a low influence on the antibiotic properties of the natural compound 1. Although merely speculative, acetylation at position 2 of ring I might have a small influence on the stability of the drug/Asite complex. In fact, according to the structural information available, ${ }^{5-7}$ the amino group located at this position of the antibiotic is not involved in any key contact with the RNA target, and therefore acetylated $\mathbf{1}$ might retain a significant activity.

Finally, the effect of neomycin-B flexibility on its enzymatic inactivation by Enterococcus faecalis APH(3') was tested. This enzyme catalyzes the transfer of a phosphate group from ATP to position 4 (see Scheme 1) of ring I. In this case, the X-ray structure of the enzyme in complex with neomycin-B shows that the antibiotic structure recognized by the enzyme and the target RNA are remarkably similar (see Scheme 1). In fact, they mainly differ in the conformation adopted by the furanose ring of III (C3-endo and close to C2-endo for the RNA- and enzymebound conformations, respectively).

As shown in Figure 11, at $100 \mu \mathrm{M}$ neomycin-B, $100 \mu \mathrm{M}$

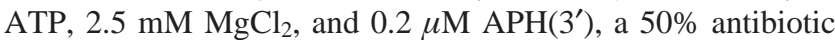
transformation is achieved in $17 \mathrm{~min}$, and the reaction is almost complete in $40 \mathrm{~min}$. Under identical conditions, the enzyme needs $35 \mathrm{~min}$ to modify $50 \%$ of analogue $\mathbf{3}$. For the more rigid derivative 2 , the reaction is even slower (around $100 \mathrm{~min}$ for a $50 \%$ transformation). In conclusion, although the extra rigidity

b)

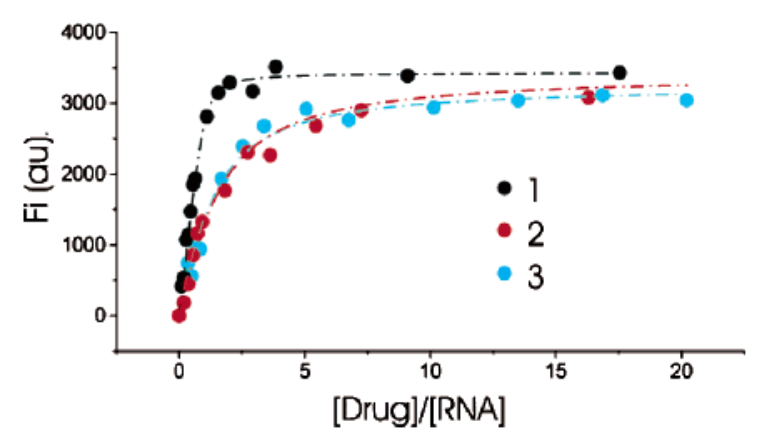

Figure 7. (a) Schematic representation of the modified RNA fragment employed in our binding studies and the structural change induced by aminoglycoside binding. (b) Some representative binding curves obtained for derivatives $\mathbf{1}$ (black), $\mathbf{2}$ (red) and $\mathbf{3}$ (cyan) under identical conditions. 
a)

\begin{tabular}{cc}
\hline Compound & $\mathrm{Kd}(\boldsymbol{\mu} \boldsymbol{M})$ \\
\hline $\mathbf{1}$ & 0.07 \\
$\mathbf{2}$ & 1.11 \\
$\mathbf{3}$ & 0.90 \\
$\mathbf{4}$ & 1.25 \\
$\mathbf{5}$ & 0.83 \\
$\mathbf{6}$ & 0.76 \\
\hline
\end{tabular}

b)

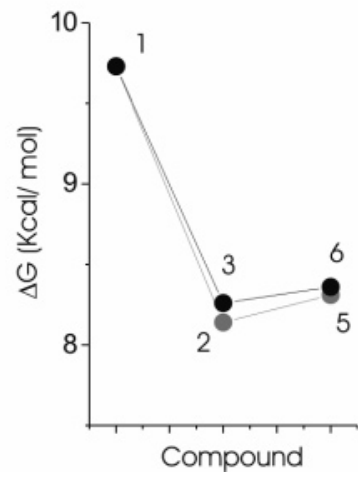

Figure 8. (a) Kd values obtanied for aminoglycosides 1-6. (b) Schematic representation of the $\Delta G$ values measured for the binding of aminoglycosides $1,2,3,5$ and $\mathbf{6}$ to the A-site.

of the locked derivatives provides a certain protection against modification by $\mathrm{APH}\left(3^{\prime}\right)$, in this case, it is insufficient to prevent the enzymatic inactivation of the drugs. This result is not totally unexpected, given the close similarity of the aminoglycoside structures in the binding pockets of both receptors (the A-site RNA and the enzyme). $6,7,19$

The in vivo activities of neomycin-B (1) and mimic $\mathbf{2}$ were tested employing the bacteria $E$. coli $\mathrm{DH} 5 \alpha(\mathrm{pACYC} 177)$, which expresses the resistance enzyme APH(3'). The MIC values for the natural antibiotic and cyclic derivatives $\mathbf{2}$ and $\mathbf{3}$ were in all cases $>150 \mu \mathrm{g} / \mathrm{mL}$. Therefore, in this case, although the extra rigidity present in compound $\mathbf{2}$ provides a certain in vitro protection against the antibiotic enzymatic inactivation, this is clearly insufficient to warrant a good biological activity.

\section{Conclusions}

We have shown that the conformational differences exhibited by aminoglycosides within the binding pockets of the ribosome and of those enzymes involved in bacterial resistance can, in certain favorable cases, be exploited for designing new antibiotic derivatives not susceptible to enzymatic inactivation. Thus, the

neomycin-B locked derivatives $\mathbf{2}$ and $\mathbf{3}$ have been specifically designed to mimic the bioactive RNA-bound structure of the drug. In fact, both antibiotics maintain a reasonable affinity for the target A-site RNA and exhibit significant biological activities. For compound 2, the conformational constraint provides full protection against the aminoglycoside modification by Staphylococcus aureus ANT(4') and Mycobacterium tuberculosis $\mathrm{AAC}\left(2^{\prime}\right)$ and partially protects against modification by Enterococcus faecalis APH(3'). In fact, 2 presents an improved biological activity with respect to neomycin-B in bacteria expressing Staphylococcus aureus ANT(4'). In addition, derivative $\mathbf{3}$ is not susceptible to modification by Mycobacterium tuberculosis $\mathrm{AAC}\left(2^{\prime}\right)$. However, for derivatives $\mathbf{2}$ and $\mathbf{3}$, the price paid in terms of RNA binding affinity is not negligible (around $1.6 \mathrm{kcal} / \mathrm{mol}$ in $\Delta G$ ). Clearly, more structure activity studies are needed in the future to address this problem. Interestingly, our RNA binding studies show that for these compounds the observed decrease in affinity has its origin, mainly, in the loss of the $\mathrm{OH}$ at position 5 of ring III. In contrast, the conformational restriction does not seem to be critical. According to X-ray studies $\mathrm{OH} 5_{\mathrm{III}}$ is involved in a hydrogen bond with G1491 in the neomycin-B/ribosome complex. Our results indicate that this particular interaction plays a significant role in the stabilization of the complex. Thus by participating in a direct ligand-RNA interaction the $\mathrm{OH} 5_{\mathrm{III}}$ might help to maintain an appropriate orientation of units III and IV within the RNA binding pocket. ${ }^{32}$ Therefore, efforts should be made in future to optimize the ligand-RNA contacts established by rings III and IV while maintaining the conformational restriction.

In our opinion, this example represents a test case for the validity of a structure-based approach for the design and preparation of ligands that specifically interact with a given receptor and that, in this particular case, might potentially be used as antibiotics. Finally, we would like to stress that the utility of conformational restriction to prevent the enzymatic inactivation of a particular drug while preserving its biological activity might not be restricted to aminoglycosides and could find further applications within medicinal chemistry.
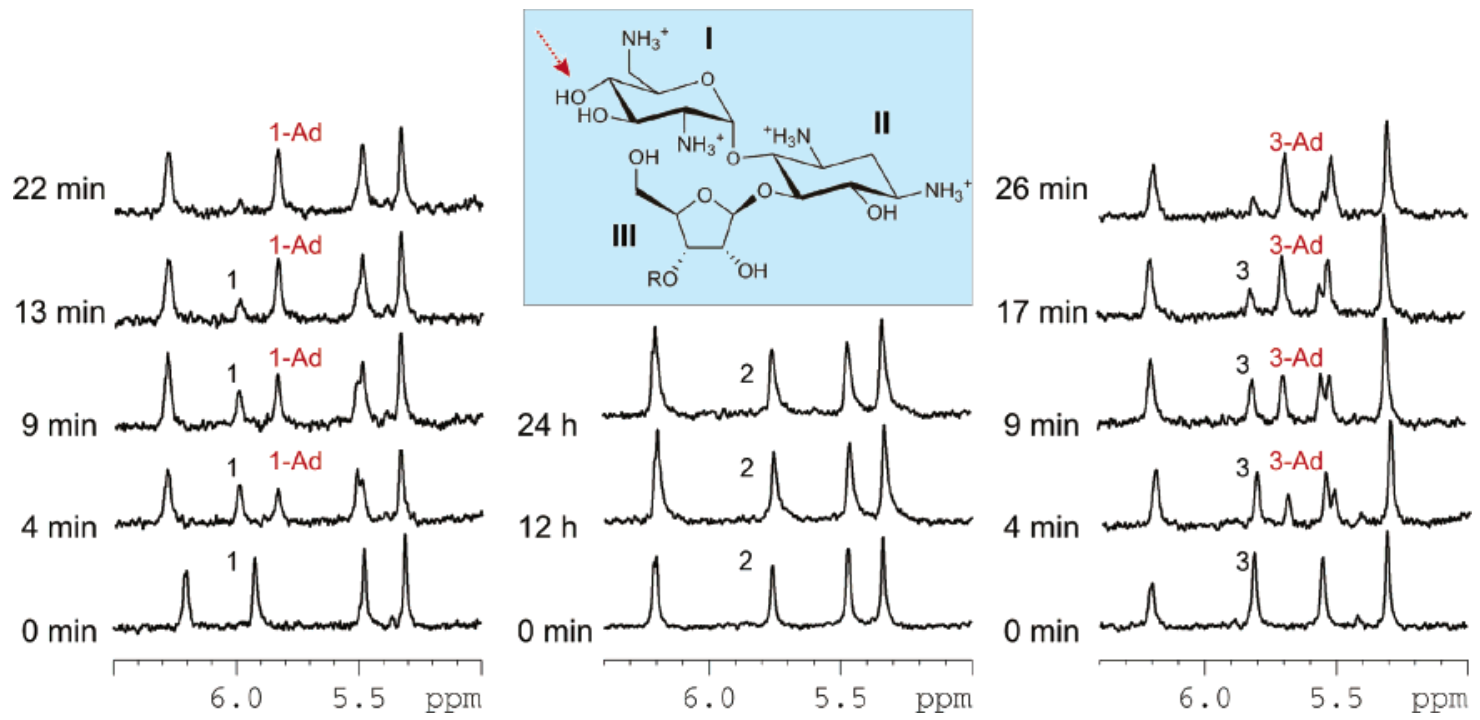

Figure 9. Time evolution (at $\mathrm{pH} 7.0$ and $310 \mathrm{~K}$ ) of neomycin-B (1, left), derivative $\mathbf{2}$ (middle), and derivative $\mathbf{3}$ (right) at $100 \mu \mathrm{M}$ concentration in the presence of ATP $(100 \mu \mathrm{M})$, phosphate $(10 \mathrm{mM})$, and $\mathrm{MgCl}_{2}(2.5 \mathrm{mM})$ after addition of $0.2 \mu \mathrm{M}$ ANT $\left(4^{\prime}\right)$ followed by 1-D NMR. For derivative 2 , no reaction was detected. 1-Ad and 3-Ad stand for the adenylated derivatives $\mathbf{1}$ and 3, respectively. The aminoglycoside position modified by the enzyme is shown schematically in the inset. 

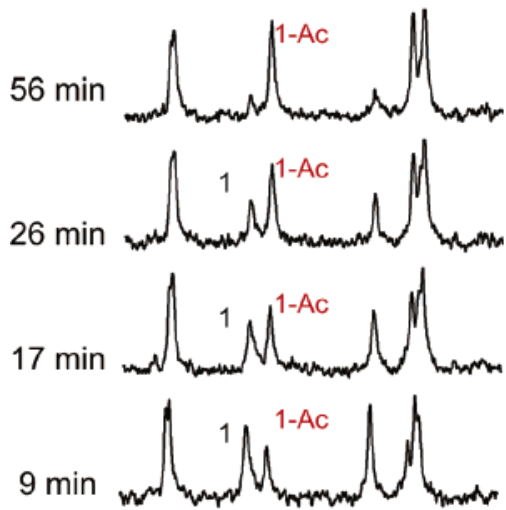

$0 \min$

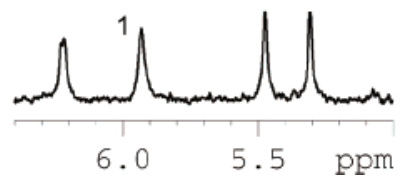

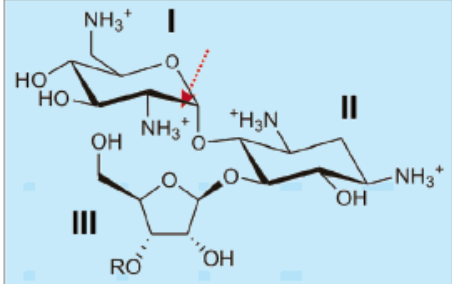

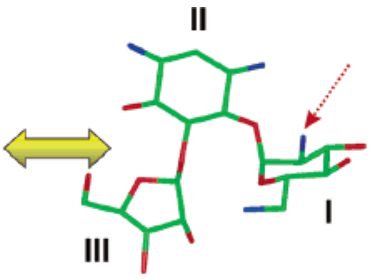

$24 \mathrm{~h}$

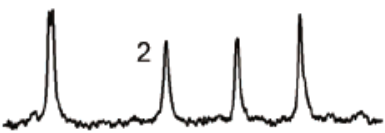

$12 \mathrm{~h}$

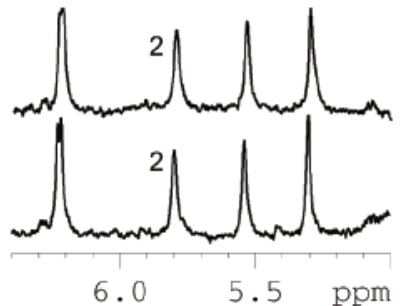

$24 \mathrm{~h}$

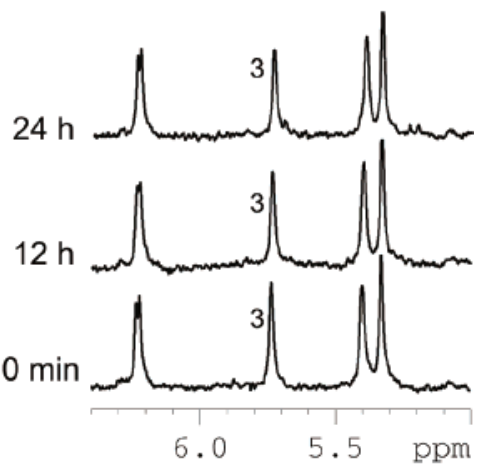

Figure 10. Time evolution (at $\mathrm{pH} 7.0$ and $310 \mathrm{~K}$ ) of neomycin-B (left), derivative 2 (middle), and derivative 3 (right) at $100 \mu \mathrm{M}$ concentration in the presence of AcCoA $(100 \mu \mathrm{M})$ and phosphate $(10 \mathrm{mM})$ after addition of $0.2 \mu \mathrm{M} \mathrm{AAC}\left(2^{\prime}\right)$, followed by 1-D NMR. For derivatives 2 and $\mathbf{3}$, no reaction was detected even after $24 \mathrm{~h}$, independently of the concentration of the enzyme employed. 1-Ac stands for acetylated neomycin-B. The aminoglycoside position modified by the enzyme is shown schematically in the inset. The X-ray structure of ribostamycin in complex with AAC $\left(2^{\prime}\right)$ is also represented.
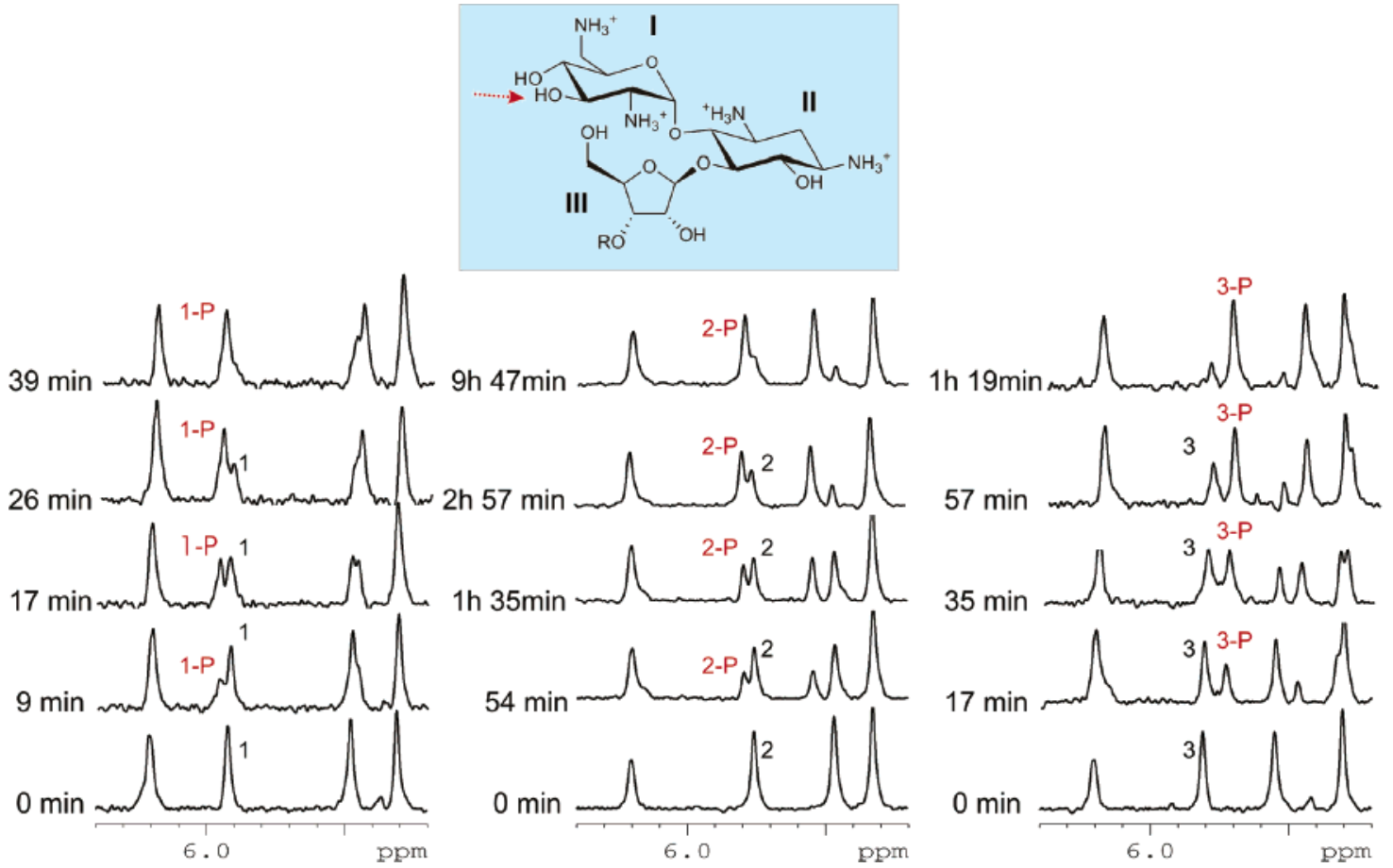

Figure 11. Time evolution (at $\mathrm{pH} 7.0$ and $310 \mathrm{~K}$ ) of neomycin-B (left), derivative 2 (middle), and derivative $\mathbf{3}$ (right) at $100 \mu \mathrm{M}$ concentration in the presence of ATP $(100 \mu \mathrm{M})$, phosphate $(10 \mathrm{mM})$, and $\mathrm{MgCl}_{2}(2.5 \mathrm{mM})$ after addition of $0.2 \mu \mathrm{M} \mathrm{APH}\left(3^{\prime}\right)$ followed by NMR. 1-P, 2-P, and 3-P stand for the modified antibiotics $\mathbf{1}, \mathbf{2}$ and $\mathbf{3}$, respectively. The aminoglycoside position modified by the enzyme is shown schematically in the inset.

\section{Materials and Methods}

Synthesis of the Aminoglycoside Derivatives. Compound 8. Compound 7 (500 mg, $0.34 \mathrm{mmol})$ was dissolved in pyridine $(10 \mathrm{~mL})$, and 2,4,6-triisopropylbenzene sulfonyl chloride (3.2 g, $10.6 \mathrm{mmol})$ was added under argon at rt. After stirring for $72 \mathrm{~h}$, the mixture was diluted with EtOAc $(300 \mathrm{~mL})$ and $\mathrm{H}_{2} \mathrm{O}(100 \mathrm{~mL})$ and then neutralized with 1 $\mathrm{N} \mathrm{HCl}$. The aqueous phase was extracted with EtOAc $(2 \times 100 \mathrm{~mL})$, and the combined organic layers were washed with brine $(50 \mathrm{~mL})$, dried over $\mathrm{Na}_{2} \mathrm{SO}_{4}$, and evaporated at reduced pressure; the crude was purified by column chromatography on silica gel $\left(\mathrm{CH}_{2} \mathrm{Cl}_{2} / \mathrm{MeOH}, 20: 1\right)$ to give 8 (250 mg, 44\%). $R_{f}=0.5\left(\mathrm{CH}_{2} \mathrm{Cl}_{2} / \mathrm{MeOH} 10: 1\right) .{ }^{1} \mathrm{H}$ NMR $(500.13$
$\mathrm{MHz}, \mathrm{CD}_{3} \mathrm{OD}$ ): $\delta 7.4-7.2\left(\mathrm{~m}, 30 \mathrm{H}, \mathrm{CH}_{2} P h\right), 5.43$ (broad s, anomeric proton), 5.24 (broad s, anomeric proton), 5.08 (broad $\mathrm{s}$, anomeric proton), 5.2-5.0 (m, 12H, $\left.\mathrm{CH}_{2} \mathrm{Ph}\right), 2.91\left(\mathrm{~m}, 3 \mathrm{H}, \mathrm{CH}\left(\mathrm{CH}_{3}\right)_{2}\right), 1.21(18 \mathrm{H}$, $\left.\mathrm{CH}\left(\mathrm{CH}_{3}\right)_{2}\right) \cdot{ }^{13} \mathrm{C} \mathrm{NMR}\left(75.47 \mathrm{MHz}, \mathrm{CD}_{3} \mathrm{OD}\right): 130-129\left(\mathrm{CH}_{2} \mathrm{Ph}\right), 111.0$ (anomeric carbon), 99.8 (anomeric carbon), 99.0 (anomeric carbon), 69-68, $\left(\mathrm{CH}_{2} \mathrm{Ph}\right), 35.5\left(\mathrm{CH}\left(\mathrm{CH}_{3}\right)_{2}\right), 35.4\left(\mathrm{C}_{\mathrm{II}}\right), 25.4\left(\mathrm{CH}\left(\mathrm{CH}_{3}\right)_{2}\right), 81.8$, 81.1, 71.8, 71.2, 69.3, 57.7, 54.2, 52.8, 52.6, 43.3, 42.8. MALDI-TOF $\mathrm{m} / z 1708.3\left[\mathrm{M}+\mathrm{Na}^{+}\right]$.

Compound 9. Palladium on charcoal (1:5 catalyst/substrate by weight) was added to a solution of $8(50 \mathrm{mg}, 0.030 \mathrm{mmol})$ and trifluoroacetic acid $(20 \mu \mathrm{L}, 0.26 \mathrm{mmol})$ in $\mathrm{MeOH}(3 \mathrm{~mL})$. After the 
suspension was stirred under $\mathrm{H}_{2}$ (1 atm), at $\mathrm{rt}$ for $8 \mathrm{~h}$, the catalyst was removed by filtration, and the solvent was evaporated to give 9 (24 $\mathrm{mg}, 90 \%$ ), which was used in the next step without further purification. $R_{f}=0.21\left(\mathrm{NH}_{4} \mathrm{OH} / \mathrm{CHCl}_{3} / n-\mathrm{BuOH} / \mathrm{EtOH} 3: 1: 2: 2.5\right){ }^{1} \mathrm{H}$ NMR $(500.13$ $\left.\mathrm{MHz}, \mathrm{D}_{2} \mathrm{O}\right): \delta 5.55\left(\right.$ broad s, $\left.1 \mathrm{H}, \mathrm{H}_{\mathrm{I}}\right), 5.25$ (broad s, $\left.1 \mathrm{H}, \mathrm{H} 1_{\mathrm{III}}\right), 5.01$ (broad s, 1H, H1 $\left.1_{\mathrm{IV}}\right), 1.90$ (m, 1H, H2 $2_{\mathrm{II}}$ equatorial), $1.15\left(\mathrm{~m}, 1 \mathrm{H}, \mathrm{H} 2_{\mathrm{II}}\right.$ axial). MALDI-TOF $m / z, 903.7\left[\mathrm{M}+\mathrm{Na}^{+}\right]$.

Compound 2. A diluted solution of $9(50 \mathrm{mg}, 0.056 \mathrm{mmol})$ in $\mathrm{H}_{2} \mathrm{O}$ (100 mL, pH 7.0) was stirred at $60{ }^{\circ} \mathrm{C}$ for 5 days. The solvent was removed at reduced pressure, and the crude was purified by ion exchange column chromatography $(0.5 \mathrm{~cm} \times 7 \mathrm{~cm})$ with Amberlite CG-50 $\left(0-7.5 \% \mathrm{NH}_{4} \mathrm{OH}\right)$ to give, after lyophilization, compound 2 (18 mg, 56\%). $R_{f}=0.16\left(\mathrm{NH}_{4} \mathrm{OH} / \mathrm{CHCl}_{3} / n-\mathrm{BuOH} / \mathrm{EtOH} 3: 1: 2: 2.5\right)$. ${ }^{1} \mathrm{H}$ NMR (500.13 MHz, $\left.\mathrm{D}_{2} \mathrm{O}\right): \delta 5.75\left(\mathrm{~d}, J=3.9 \mathrm{~Hz}, 1 \mathrm{H}, \mathrm{H} 1_{\mathrm{III}}\right), 5.20$ (d, $\left.J=3.5 \mathrm{~Hz}, 1 \mathrm{H}, \mathrm{H} 1_{\mathrm{I}}\right), 5.03$ (broad s, $\left.1 \mathrm{H}, \mathrm{H} 1_{\mathrm{IV}}\right), 2.72\left(1 \mathrm{H}, \mathrm{H} 5_{\mathrm{III}}\right)$, $2.55\left(1 \mathrm{H}, \mathrm{H} 2_{\mathrm{I}}\right), 1.95$ (m, 1H, $\mathrm{H} 2_{\mathrm{II}}$ equatorial), 1.16 ( $\mathrm{m}, 1 \mathrm{H}, \mathrm{H} 2_{\mathrm{II}}$ axial). ${ }^{13} \mathrm{C}$ NMR $\left(75.47 \mathrm{MHz}, \mathrm{D}_{2} \mathrm{O}\right): \delta 100.3\left(\mathrm{Cl}_{\mathrm{IV}}\right), 109.5\left(\mathrm{Cl}_{\mathrm{III}}\right), 98.2\left(\mathrm{Cl}_{\mathrm{I}}\right)$, 60.7 (C2 $\left.{ }_{\mathrm{I}}\right), 48.4\left(\mathrm{C}_{\text {III }}\right)$. MALDI-TOF $m / z 619.1\left[\mathrm{M}+\mathrm{Na}^{+}\right]$.

Compound 10. To a solution of compound $7(1.0 \mathrm{~g}, 0.7 \mathrm{mmol})$ in dry THF $(7 \mathrm{~mL})$ at $0{ }^{\circ} \mathrm{C}$ under argon was added 2,6-lutidine $(0.24 \mathrm{~mL}$, $2.1 \mathrm{mmol})$ and TIPSOTf $(0.28 \mathrm{~mL}, 1.05 \mathrm{mmol})$. The mixture was allowed to warm to $\mathrm{rt}$ and stirred for $1 \mathrm{~h}$. The solvent was evaporated, and the crude was purified by flash chromatography $\left(\mathrm{CH}_{2} \mathrm{Cl}_{2} / \mathrm{MeOH}\right.$, 15:1) to give the silyl ether derivative $(0.88 \mathrm{~g}, 80 \%) . R_{f}=0.4\left(\mathrm{CH}_{2} \mathrm{Cl}_{2} /\right.$ $\mathrm{MeOH} 10: 1)$. To a solution of this derivative $(1.0 \mathrm{~g}, 0.63 \mathrm{mmol})$ in pyridine $(15 \mathrm{~mL})$ was added at $\mathrm{rt} \mathrm{Ac}_{2} \mathrm{O}(7 \mathrm{~mL})$. After the mixture was stirred for $5 \mathrm{~h}$ at $\mathrm{rt}$, the solvent was removed at reduced pressure, and the crude was purified by column chromatography on silica gel (EtOAc/ hexane, 1:1) to give $\mathbf{1 0}(1.02 \mathrm{~g}, 100 \%) . R_{f}=0.6$ (EtOAc/hexane 2:1). ${ }^{1} \mathrm{H}$ NMR (500.13 MHz, CD $\left.{ }_{3} \mathrm{OD}\right): \delta 7.4-7.2\left(\mathrm{~m}, 30 \mathrm{H}, \mathrm{CH}_{2} P h\right), 5.2-$ $5.0\left(12 \mathrm{H}, \mathrm{CH}_{2} \mathrm{Ph}\right), 2.1-1.8\left(18 \mathrm{H}, \mathrm{CH}_{3} \mathrm{CO}_{2}\right), 1.97\left(\mathrm{~m}, 1 \mathrm{H}, \mathrm{H} 2_{\mathrm{II}}\right.$ equatorial), $1.36\left(\mathrm{~m}, 1 \mathrm{H}, \mathrm{H} 2_{\mathrm{II}}\right.$ axial), $1.32\left(\mathrm{~m}, 3 \mathrm{H}, \mathrm{SiCH}\left(\mathrm{CH}_{3}\right)_{2}\right), 1.10$ $\left(18 \mathrm{H}, \mathrm{SiCH}\left(\mathrm{CH}_{3}\right)_{2}\right) .{ }^{13} \mathrm{C} \mathrm{NMR}\left(75.47 \mathrm{MHz}, \mathrm{CD}_{3} \mathrm{OD}\right): 130-129$ $\left(\mathrm{CH}_{2} \mathrm{Ph}\right), 69-68,\left(\mathrm{CH}_{2} \mathrm{Ph}\right), 35.4\left(\mathrm{C}_{\mathrm{II}}\right), 21-20\left(\mathrm{CH}_{3} \mathrm{CO}_{2}\right), 18.5$ $\left(\mathrm{SiCH}\left(\mathrm{CH}_{3}\right)_{2}\right)$. MALDI-TOF $m / z$, $1850.2\left[\mathrm{M}+\mathrm{Na}^{+}\right]$.

Compound 11. To a solution of the silyl ether $10(0.5 \mathrm{~g}, 0.28 \mathrm{mmol})$ in dry THF $(5 \mathrm{~mL})$, in a polyethylene vessel at $0{ }^{\circ} \mathrm{C}$, was added $\mathrm{HF} /$ pyridine $(0.3 \mathrm{~mL})$. After stirring at $\mathrm{rt}$ for $5 \mathrm{~h}$, the mixture was diluted with $\mathrm{Et}_{2} \mathrm{O}$ and neutralized with aqueous saturated $\mathrm{NaHCO}_{3}$. The combined organic layer was dried, evaporated, and purified by flash chromatography (EtOAc/hexane, 1:1) to give alcohol 11 (0.42 g, 90\%). $R_{f}=0.3$ (AcOEt/hexane 2:1). ${ }^{1} \mathrm{H}$ NMR $\left(500.13 \mathrm{MHz}, \mathrm{CD}_{3} \mathrm{OD}\right): \delta$ 7.4-7.2 (m, 30H, $\left.\mathrm{CH}_{2} P h\right), 5.81$ (broad s, anomeric proton), 5.72 (broad $\mathrm{s}$, anomeric proton), 5.18 (broad s, anomeric proton), $5.2-4.9(\mathrm{~m}, 12 \mathrm{H}$, $\left.\mathrm{CH}_{2} \mathrm{Ph}\right), 2.2-1.9\left(18 \mathrm{H}, \mathrm{CH}_{3} \mathrm{CO}_{2}\right) 1.95(\mathrm{~m}, 1 \mathrm{H}, \mathrm{H} 2$ II equatorial), 1,64 (m, 1H, H2 2 II axial). ${ }^{13} \mathrm{C}$ NMR (75.47 $\mathrm{MHz}, \mathrm{CD}_{3} \mathrm{OD}$ ): $130-129$ $\left(\mathrm{CH}_{2} \mathrm{Ph}\right), 110.5$ (anomeric carbon), 98.2 (anomeric carbon), 68-67, $\left(\mathrm{CH}_{2} \mathrm{Ph}\right), 34.4\left(\mathrm{C}_{\mathrm{II}}\right), 21-20\left(\mathrm{CH}_{3} \mathrm{CO}_{2}\right), 84.1,83.4,76.1,74.1,72.4$, 69.8, 62.4, 54.9, 51.1, 42.1. MALDI-TOF $m / z$ 1694.6 [M $\left.+\mathrm{Na}^{+}\right]$.

Compound 12. Dess - Martin periodinane ( $95 \mathrm{mg}, 0.26 \mathrm{mmol}$ ) was added to a solution of alcohol $11(250 \mathrm{mg}, 0.15 \mathrm{mmol})$ in $\mathrm{CH}_{2} \mathrm{Cl}_{2}(5$ $\mathrm{mL})$. After the mixture was stirred for $2 \mathrm{~h}$ at $\mathrm{rt}, \mathrm{Et}_{2} \mathrm{O}$ was added $(20$ $\mathrm{mL}$ ), and the mixture was poured into saturated aqueous $\mathrm{NaHCO}_{3}$ solution $(25 \mathrm{~mL})$ and $\mathrm{Na}_{2} \mathrm{~S}_{2} \mathrm{O}_{5}(100 \mathrm{mg})$. The organic layer was washed with saturated aqueous $\mathrm{NaHCO}_{3}(25 \mathrm{~mL})$ and brine $(25 \mathrm{~mL})$ and dried, and the solvent evaporated at reduced presure to give, after purification by flash chromatography (EtOAc/hexane, 2:1), aldehyde 12 (199 mg, $79 \%) . R_{f}=0.3$ (AcOEt/hexane 2:1). ${ }^{1} \mathrm{H}$ NMR $\left(500.13 \mathrm{MHz}, \mathrm{CDCl}_{3}\right)$ : $\delta 9.4$ (broad s, $1 \mathrm{H}, \mathrm{CHO}), 7.4-7.2\left(\mathrm{~m}, 30 \mathrm{H}, \mathrm{CH}_{2} P h\right), 5.2-4.9(12 \mathrm{H}$, $\left.\mathrm{CH}_{2} \mathrm{Ph}\right), 2.1-1.9\left(18 \mathrm{H}, \mathrm{CH}_{3} \mathrm{CO}_{2}\right), 1.92\left(\mathrm{~m}, 1 \mathrm{H}, \mathrm{H} 2_{\text {II }}\right.$ equatorial), 1.41 (m, 1H, $\mathrm{H}_{\text {II }}$ axial). ${ }^{13} \mathrm{C}$ NMR $\left(75.47 \mathrm{MHz}, \mathrm{CDCl}_{3}\right): 130-129$ $\left(\mathrm{CH}_{2} \mathrm{Ph}\right), 68-67,\left(\mathrm{CH}_{2} \mathrm{Ph}\right), 34.6\left(\mathrm{C} 2_{\mathrm{II}}\right), 21-20\left(\mathrm{CH}_{3} \mathrm{CO}_{2}\right)$. MALDITOF $m / z, 1691.58\left[\mathrm{M}+\mathrm{Na}^{+}\right]$.

Compound 13. To a solution of $\mathbf{1 2}(250 \mathrm{mg}, 0.15 \mathrm{mmol})$ in dry acetonitrile $(6 \mathrm{~mL})$ was added (methoxycarbonylmethylen)triphenylphosphorane $(66 \mathrm{mg}, 0.19 \mathrm{mmol})$. After stirring at $\mathrm{rt}$ for $3 \mathrm{~h}$, the solvent was removed at reduced pressure, and the crude was purified by column chromatography on silica gel (EtOAc/hexane, 1:1) to give compound $13(215 \mathrm{mg}, 82 \%) . R_{f}=0.3$ (AcOEt/hexane 2:1). ${ }^{1} \mathrm{H}$ NMR $(500.13$ $\left.\mathrm{MHz} \mathrm{CDCl}_{3}\right): \delta 7.4-7.2\left(\mathrm{~m}, 30 \mathrm{H}, \mathrm{CH}_{2} P h\right), 7.16($ broad $\mathrm{m}, 1 \mathrm{H}), 6.33$ (broad s, $1 \mathrm{H}), 5.2-4.9\left(12 \mathrm{H}, \mathrm{CH}_{2} \mathrm{Ph}\right), 3.90\left(\mathrm{~s}, 3 \mathrm{H}, \mathrm{CO}_{2} \mathrm{CH}_{3}\right), 2.1-1.8$ (18H, $\left.\mathrm{CH}_{3} \mathrm{CO}_{2}\right), 1.98\left(\mathrm{~m}, 1 \mathrm{H}, \mathrm{H} 2_{\text {II }}\right.$ equatorial), 1,40 (m, $1 \mathrm{H}, \mathrm{H} 2_{\text {II }}$ axial). ${ }^{13} \mathrm{C}$ NMR $\left(75.47 \mathrm{MHz}, \mathrm{CDCl}_{3}\right): 130-129\left(\mathrm{CH}_{2} \mathrm{Ph}\right), 68-67\left(\mathrm{CH}_{2} \mathrm{Ph}\right)$, $34.6\left(\mathrm{C}_{\mathrm{II}}\right), 21-20\left(\mathrm{CH}_{3} \mathrm{CO}_{2}\right)$. MALDI-TOF $\mathrm{m} / z .1748 .7\left[\mathrm{M}+\mathrm{Na}^{+}\right]$.

Compound 14. To a solution of compound $13(200 \mathrm{mg}, 0.12 \mathrm{mmol})$ in THF/EtOH $(1: 2,10 \mathrm{~mL})$ at rt was added $\mathrm{NaBH}_{4}(54 \mathrm{mg}, 1.46 \mathrm{mmol})$ and $\mathrm{LiCl}(6 \mathrm{mg}, 0.15 \mathrm{mmol})$. After the mixture was stirred at $\mathrm{rt}$ for 12 $\mathrm{h}$, EtOAc $(25 \mathrm{~mL})$ was added, and the mixture was washed with aqueous saturated $\mathrm{NaHCO}_{3}$ and brine. The organic phase was dried over $\mathrm{Na}_{2} \mathrm{SO}_{4}$, the solvent was removed at reduced pressure, and the crude was purified by flash chromatography $\left(\mathrm{CH}_{2} \mathrm{Cl}_{2} / \mathrm{MeOH}, 20: 1\right)$ to give 14 (155 mg, 89\%). $R_{f}=0.4\left(\mathrm{CH}_{2} \mathrm{Cl}_{2} / \mathrm{MeOH} 10: 1\right) .{ }^{1} \mathrm{H} \mathrm{NMR}$ (500.13 MHz, $\left.\mathrm{CD}_{3} \mathrm{OD}\right): \delta 7.4-7.2\left(\mathrm{~m}, 30 \mathrm{H}, \mathrm{CH}_{2} P h\right), 5.16$ (broad s, $\left.1 \mathrm{H}, \mathrm{H}_{\mathrm{I}}\right), 5.04$ (broad s, $\left.1 \mathrm{H}, \mathrm{H} 1_{\mathrm{III}}\right), 5.2-5.0\left(12 \mathrm{H}, \mathrm{CH}_{2} \mathrm{Ph}\right), 4.78$ (broad $\left.\mathrm{s}, 1 \mathrm{H}, \mathrm{H} 1_{\mathrm{IV}}\right), 1.99\left(\mathrm{~m}, 1 \mathrm{H}, \mathrm{H} 2_{\mathrm{II}}\right.$ equatorial), $1.62-1.60\left(\mathrm{~m}, 4 \mathrm{H},-\mathrm{CH}_{2}-\right.$ $\left.\mathrm{CH}_{2}-\mathrm{CH}_{2}-\mathrm{OH}\right), 1.39$ (m, $1 \mathrm{H}, \mathrm{H} 2_{\text {II }}$ axial). ${ }^{13} \mathrm{C}$ NMR $\left(75.47 \mathrm{MHz}, \mathrm{CD}_{3-}\right.$ OD): $130-129\left(\mathrm{CH}_{2} \mathrm{Ph}\right), 111.3\left(\mathrm{Cl}_{\mathrm{III}}\right), 101.2\left(\mathrm{Cl}_{\mathrm{I}}\right), 100.9\left(\mathrm{C}_{\mathrm{IV}}\right), 69-$ 68, $\left(\mathrm{CH}_{2} \mathrm{Ph}\right), 35.1\left(\mathrm{C} 2_{\mathrm{II}}\right), 30.6\left(-\mathrm{CH}_{2}-\mathrm{CH}_{2}-\mathrm{CH}_{2}-\mathrm{OH}\right), 29.5\left(-\mathrm{CH}_{2}-\right.$ $\left.\mathrm{CH}_{2}-\mathrm{CH}_{2}-\mathrm{OH}\right), 86.8,82.8,76.4,74.9,73.6,73.4,72.9,71.6,69.4$, 63.0, 57.7, 54.2, 52.6, 43.1, 42.5. MALDI-TOF $m / z, 1469.7\left[\mathrm{M}+\mathrm{Na}^{+}\right]$.

Compound 15. Treatment of compound $14(150 \mathrm{mg}, 0.10 \mathrm{mmol})$ at $0{ }^{\circ} \mathrm{C}$ following the same procedure described for the preparation of compound 10 gave the silyl ether $15(97 \mathrm{mg}, 60 \%) . R_{f}=0.4\left(\mathrm{CH}_{2} \mathrm{Cl}_{2} /\right.$ $\mathrm{MeOH} 10: 1) .{ }^{1} \mathrm{H}$ NMR $\left(500.13 \mathrm{MHz}, \mathrm{CD}_{3} \mathrm{OD}\right): \delta 7.4-7.2(\mathrm{~m}, 30 \mathrm{H}$, $\mathrm{CH}_{2} \mathrm{Ph}$ ), 5.26 (broad s, 1H, H1 1 ), 5.07 (broad s, 1H, H1 $1_{\mathrm{III}}$ ), 5.2-5.0 $\left(12 \mathrm{H}, \mathrm{CH}_{2} \mathrm{Ph}\right), 4.85$ (broad s, $\left.1 \mathrm{H}, \mathrm{H} 1_{\mathrm{IV}}\right), 1.96\left(\mathrm{~m}, 1 \mathrm{H}, \mathrm{H} 2_{\text {II }}\right.$ equatorial), $1.66-1.63\left(\mathrm{~m}, 4 \mathrm{H},-\mathrm{CH}_{2}-\mathrm{CH}_{2}-\mathrm{CH}_{2}-\mathrm{OTIPS}\right), 1,38\left(\mathrm{~m}, 1 \mathrm{H}, \mathrm{H} 2_{\mathrm{II}}\right.$ axial), 1.04 (18H, $\left.\mathrm{CH}\left(\mathrm{CH}_{3}\right)_{2}\right) .{ }^{13} \mathrm{C} \mathrm{NMR}\left(75.47 \mathrm{MHz}, \mathrm{CD}_{3} \mathrm{OD}\right): 130-$ $129\left(\mathrm{CH}_{2} \mathrm{Ph}\right), 111.0\left(\mathrm{Cl}_{\mathrm{III}}\right), 100.7\left(\mathrm{Cl}_{\mathrm{IV}}\right), 100.5\left(\mathrm{Cl}_{\mathrm{I}}\right), 69-68,\left(\mathrm{CH}_{2} \mathrm{Ph}\right)$, 35.1 (C2 $\left.{ }_{\text {II }}\right), 31.1\left(-\mathrm{CH}_{2}-\mathrm{CH}_{2}-\mathrm{CH}_{2}-\mathrm{OTIPS}\right), 26.7\left(-\mathrm{CH}_{2}-\mathrm{CH}_{2}-\right.$ $\mathrm{CH}_{2}$-OTIPS), $18.31\left(\mathrm{CH}\left(\mathrm{CH}_{3}\right)_{2}\right), 86.7,82.7,82.2,75.8,74.7,73.5$, $73.1,72.0,69.3,64.8,57.9,54.3,53.3,52.5,43.4,42.5$. MALDI-TOF $m / z, 1626.2\left[\mathrm{M}+\mathrm{Na}^{+}\right]$.

Compound 16. Acetylation of $\mathbf{1 5}$ (97 mg, $0.060 \mathrm{mmol}$ ) employing the same methodology described for $\mathbf{1 0}$ gave the fully acetylated derivative in quantitative yield. $R_{f}=0.3\left(\mathrm{CH}_{2} \mathrm{Cl}_{2} / \mathrm{MeOH} 20: 1\right)$. From this compound $(111 \mathrm{mg}, 0.060 \mathrm{mmol})$, derivative 16 (81 $\mathrm{mg}, 0.048$ mmol) was obtained following a procedure identical to that described for 11; yield: $79 \% . R_{f}=0.25\left(\mathrm{CH}_{2} \mathrm{Cl}_{2} / \mathrm{MeOH} 20: 1\right) .{ }^{1} \mathrm{H}$ NMR $(500.13$ $\left.\mathrm{MHz}, \mathrm{CD}_{3} \mathrm{OD}\right): \delta 7.4-7.2\left(\mathrm{~m}, 30 \mathrm{H}, \mathrm{CH}_{2} \mathrm{Ph}\right), 5.1-4.9\left(12 \mathrm{H}, \mathrm{CH}_{2} \mathrm{Ph}\right)$, 2.1-1.9 (18H, $\left.\mathrm{CH}_{3} \mathrm{CO}_{2}\right), 1.94\left(\mathrm{~m}, 1 \mathrm{H}, \mathrm{H} 2_{\mathrm{II}}\right.$ equatorial), $1.63(\mathrm{~m}, 1 \mathrm{H}$, $\mathrm{H} 2$ II axial). ${ }^{13} \mathrm{C}$ NMR $\left(75.47 \mathrm{MHz}, \mathrm{CD}_{3} \mathrm{OD}\right): 130-129\left(\mathrm{CH}_{2} \mathrm{Ph}\right), 68-$ 67, $\left(\mathrm{CH}_{2} \mathrm{Ph}\right), 34.5\left(\mathrm{C} 2_{\mathrm{II}}\right), 21-20\left(\mathrm{CH}_{3} \mathrm{CO}_{2}\right)$. MALDI-TOF $m / z .1721 .8$ $\left[\mathrm{M}+\mathrm{Na}^{+}\right]$.

Compound 17. To a solution of compound 16 (81 mg, $0.048 \mathrm{mmol})$ in pyridine $(2 \mathrm{~mL})$ was added DMAP $(1 \mathrm{mg}, 0.008 \mathrm{mmol})$ and p-toluenesulfonyl chloride $(14 \mathrm{mg}, 0.073 \mathrm{mmol})$. After stirring the mixture, at room temperature under argon for $3 \mathrm{~h}$, the solvent was evaporated and the crude was purified by flash chromatography (EtOAc/ hexane, $1: 1)$ to give the primary sulfonate $(70 \mathrm{mg}, 79 \%) . R_{f}=0.4$ $\left(\mathrm{CH}_{2} \mathrm{Cl}_{2} / \mathrm{MeOH} 20: 1\right)$. To a solution of this derivative (70 $\mathrm{mg}, 0.038$ $\mathrm{mmol})$ in $\mathrm{MeOH} / \mathrm{THF}(2: 1,300 \mu \mathrm{L})$ was added $\mathrm{KCN}(2 \mathrm{mg}, 0.031$ mmol). After stirring at room temperature for $10 \mathrm{~h}$, the solvent was removed and the crude was purified by column chromatography on silica gel $\left(\mathrm{CH}_{2} \mathrm{Cl}_{2} / \mathrm{MeOH}, 20: 1\right)$ to give the deacetylated derivative $\mathbf{1 7}$ (36 mg, 58\%). $R_{f}=0.44\left(\mathrm{CH}_{2} \mathrm{Cl}_{2} / \mathrm{MeOH} 10: 1\right) .{ }^{1} \mathrm{H} \mathrm{NMR}(500.13 \mathrm{MHz}$, $\left.\mathrm{CD}_{3} \mathrm{OD}\right): \delta 7.75(\mathrm{~d}, J=8 \mathrm{~Hz}, 2 \mathrm{H}, \mathrm{O}-T s), 7.36(\mathrm{~d}, J=8 \mathrm{~Hz}, 2 \mathrm{H}$, O-Ts), 7.4-7.2 (m, 30H, $\left.\mathrm{CH}_{2} P h\right), 5.24$ (broad s, 1H, H1 I), 5.01 (broad s, $\left.1 \mathrm{H}, \mathrm{H} 1_{\text {III }}\right), 5.2-5.0\left(12 \mathrm{H}, \mathrm{CH}_{2} \mathrm{Ph}\right), 4.81$ (broad s, $\left.1 \mathrm{H}, \mathrm{H} 1_{\mathrm{IV}}\right), 1.97$ (m, 1H, $\mathrm{H}_{\text {II }}$ equatorial), $1.65-1.60$ (m, 4H, $-\mathrm{CH}_{2}-\mathrm{CH}_{2}-\mathrm{CH}_{2}-\mathrm{OTs}$ ), 1.36 (m, $1 \mathrm{H}, \mathrm{H} 2{ }_{\text {II }}$ axial). ${ }^{13} \mathrm{C}$ NMR $\left(75.47 \mathrm{MHz}, \mathrm{CD}_{3} \mathrm{OD}\right): 130-129$ $\left(\mathrm{CH}_{2} P h\right), 111.6\left(\mathrm{Cl}_{\mathrm{III}}\right), 100.6\left(\mathrm{Cl}_{\mathrm{IV}}\right), 100.5\left(\mathrm{Cl}_{\mathrm{I}}\right), 69-68,\left(\mathrm{CH}_{2} \mathrm{Ph}\right)$, 
$35.4\left(\mathrm{C}_{\text {III }}\right), 30.8\left(-\mathrm{CH}_{2}-\mathrm{CH}_{2}-\mathrm{CH}_{2}-\mathrm{OTs}\right), 26.5\left(-\mathrm{CH}_{2}-\mathrm{CH}_{2}-\mathrm{CH}_{2}-\right.$ OTs), 86.8, 82.5, 81.9, 76.3, 73.7, 73.3, 72.2, 69.5, 68.4, 57.8, 54.6, 52.8, 52.5, 43.5, 42.6. MALDI-TOF $m / z, 1623.3\left[\mathrm{M}+\mathrm{Na}^{+}\right]$.

Compound 3. Treatment of $17(12 \mathrm{mg}, 0.0075 \mathrm{mmol})$ under the same conditions described for the preparation of compound $\mathbf{9}$ gave the fully deprotected tosilate $(5 \mathrm{mg}, 88 \%)$ which was used in the next step without further purification. $R_{f}=0.16\left(\mathrm{NH}_{4} \mathrm{OH} / \mathrm{CHCl}_{3} /{ }^{n} \mathrm{BuOH} / \mathrm{EtOH}\right.$, $3: 1: 2: 2.5)$. A diluted solution of this compound ( $5 \mathrm{mg}, 0.0066 \mathrm{mmol}$ ) in $\mathrm{H}_{2} \mathrm{O}(100 \mathrm{~mL}, \mathrm{pH} 7.0)$ was stirred at $40^{\circ} \mathrm{C}$ for 10 days. The solvent was removed at reduced pressure, and the crude was purified by ion exchange column chromatography $(0.5 \mathrm{~cm} \times 7 \mathrm{~cm})$ with Amberlite CG-50 (0-7.5\% $\left.\mathrm{NH}_{4} \mathrm{OH}\right)$ to give, after lyophilization, compound 3 (3 $\mathrm{mg}, 62 \%) . R_{f}=0.16\left(\mathrm{NH}_{4} \mathrm{OH} / \mathrm{CHCl}_{3} / n-\mathrm{BuOH} / \mathrm{EtOH} 3: 1: 2: 2.5\right) .{ }^{1} \mathrm{H}$ NMR $\left(500.13 \mathrm{MHz}, \mathrm{D}_{2} \mathrm{O}\right): 5.9\left(\mathrm{~d}, J=3.9 \mathrm{~Hz}, 1 \mathrm{H}, \mathrm{H}_{\mathrm{I}}\right), 5.5(\mathrm{~d}, J=$ $\left.3.5 \mathrm{~Hz}, 1 \mathrm{H}, \mathrm{H} 1_{\mathrm{III}}\right), 5.2$ (d, $\left.J=1.5 \mathrm{~Hz}, 1 \mathrm{H}, \mathrm{H} 1_{\mathrm{IV}}\right), 4.3\left(1 \mathrm{H}, \mathrm{H} 2_{\mathrm{III}}\right), 4.2$ $\left(1 \mathrm{H}, \mathrm{H} 4_{\mathrm{III}}\right), 3.6\left(1 \mathrm{H}, \mathrm{H} 2_{\mathrm{IV}}\right), 3.6\left(1 \mathrm{H}, \mathrm{H} 7_{\mathrm{III}}\right), 3.5\left(1 \mathrm{H}, \mathrm{H} 2_{\mathrm{I}}\right), 3.1(1 \mathrm{H}$, $\left.\mathrm{H} 7_{\text {III }}\right), 2.5\left(\mathrm{~m}, 1 \mathrm{H}, \mathrm{H} 2_{\text {II }}\right.$ equatorial), $2.3\left(1 \mathrm{H}, \mathrm{H} 5_{\mathrm{III}}\right), 2.1$ (1H, H6 $\left.6_{\text {III }}\right), 1.8$ (m, 1H, H2 ${ }_{\text {II }}$ axial), 1.7 (1H, H5 III), 1.7 (1H, H6 $\left.{ }_{\text {III }}\right) .{ }^{13} \mathrm{C}$ NMR $(75.47$ $\left.\mathrm{MHz}, \mathrm{D}_{2} \mathrm{O}\right): 108.7\left(\mathrm{C}_{\text {III }}\right), 96.4\left(\mathrm{Cl}_{\mathrm{I}}\right), 96.1\left(\mathrm{Cl}_{\mathrm{IV}}\right), 73.2\left(\mathrm{C}_{\mathrm{III}}\right), 59.3$

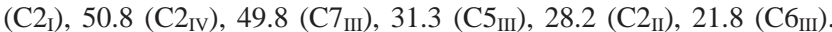
MALDI-TOF $m / z 648.1\left[\mathrm{M}+\mathrm{Na}^{+}\right]$

Compound 6. Palladium on charcoal (1:5 catalyst/substrate by weight) was added to a solution of $17(25 \mathrm{mg}, 0.016 \mathrm{mmol})$ and trifluoroacetic acid $(20 \mu \mathrm{L}, 0.26 \mathrm{mmol})$ in $\mathrm{MeOH}(3 \mathrm{~mL})$. After stirring the suspension under $\mathrm{H}_{2}(1 \mathrm{~atm})$ at room temperature for $48 \mathrm{~h}$, the catalyst was removed by filtration, and the solvent was evaporated at reduced pressure. Derivative $6(6.3 \mathrm{mg}, 0.010 \mathrm{mmol})$ was purified by ion exchange column chromatography $(0.5 \mathrm{~cm} \times 7 \mathrm{~cm})$ with Amberlite CG-50 (0-7.5\% NH $\left.\mathrm{NH}_{4} \mathrm{OH}\right)$; yield: $\sim 60 \% . R_{f}=0.24\left(\mathrm{NH}_{4} \mathrm{OH} / \mathrm{CHCl}_{3} /\right.$ $\left.{ }^{n} \mathrm{BuOH} / \mathrm{EtOH}, 3: 1: 2: 2.5\right) .{ }^{1} \mathrm{H}$ NMR $\left(500.13 \mathrm{MHz}, \mathrm{D}_{2} \mathrm{O}\right): \delta 5.9$ (broad $\mathrm{s}, 1 \mathrm{H}, \mathrm{H}_{\mathrm{I}}$ ), $5.3\left(\mathrm{~d}, J=3.5 \mathrm{~Hz}, 1 \mathrm{H}, \mathrm{H} 1_{\mathrm{III}}\right), 5.2\left(\right.$ broad s, $\left.1 \mathrm{H}, \mathrm{H} 1_{\mathrm{IV}}\right), 4.3$ $\left(1 \mathrm{H}, \mathrm{H} 2_{\mathrm{III}}\right), 3.5\left(1 \mathrm{H}, \mathrm{H} 2_{\mathrm{IV}}\right), 3.4\left(1 \mathrm{H}, \mathrm{H6}_{\mathrm{I}}\right), 3.4\left(1 \mathrm{H}, \mathrm{H} 6_{\mathrm{IV}}\right), 3.4(1 \mathrm{H}$, H6 $\left.{ }_{\text {IV }}\right), 3.3\left(1 \mathrm{H}, \mathrm{H}_{\mathrm{I}}\right), 3.2\left(1 \mathrm{H}, \mathrm{H6} 6_{\mathrm{I}}\right), 2.3\left(\mathrm{~m}, 1 \mathrm{H}, \mathrm{H} 2_{\mathrm{II}}\right.$ equatorial), 1.7 (m, 1H, H2 $2_{\text {II }}$ axial). ${ }^{13} \mathrm{C}$ NMR (75.47 MHz, $\left.\mathrm{D}_{2} \mathrm{O}\right): 109.7\left(\mathrm{C}_{\text {III }}\right), 95.7$ $\left(\mathrm{C} 1_{\mathrm{IV}}\right), 95.1\left(\mathrm{C1}_{\mathrm{I}}\right), 79.4\left(\mathrm{C} 2_{\mathrm{III}}\right), 53.5\left(\mathrm{C} 2_{\mathrm{I}}\right), 50.9\left(\mathrm{C} 2_{\mathrm{IV}}\right), 40.5\left(\mathrm{C} 6_{\mathrm{IV}}\right)$, $40.2\left(\mathrm{C6}_{\mathrm{I}}\right), 29.7\left(\mathrm{C}_{\mathrm{II}}\right)$. MALDI-TOF $\mathrm{m} / \mathrm{z} 649.8\left[\mathrm{M}+\mathrm{Na}^{+}\right]$.

NMR and Molecular Modeling of 2-4. RESP atomic charges for neomycin-B analogues $\mathbf{2}-\mathbf{4}$ were derived by applying the RESP module of the AMBER 5.0 package $^{26}$ to the HF/6-31G(d) ESP charges calculated with Gaussian-94. ${ }^{38}$ All MD simulations were carried out using the SANDER module within AMBER and the Cornell et al. force field. ${ }^{39}$ Parameters for the acetalic functions were taken from GLYCAM. ${ }^{40}$

NMR Structure of Derivatives 2-4. NMR experiments were recorded on a Varian Unity 500 and Bruker Avance 500 at $313 \mathrm{~K}$. Selective 1D NOE experiments were recorded employing the 1DDPFGSE NOE pulse sequence. NOE intensities were normalized with respect to the diagonal peak at zero mixing time. Selective $T_{1}$ measurements were performed on the anomeric and several other protons to obtain the above-mentioned values. Experimental NOEs were fitted to a double exponential function, $f(t)=p 0\left(e^{-p 1 t}\right)\left(1-e^{-p 2 t}\right)$ with $p 0, p 1$, and $p 2$ being adjustable parameters. ${ }^{41}$ The initial slope was determined from the first derivative at time $t=0, f^{\prime}(0)=p 0 p 2$. From the initial slopes, interproton distances were obtained by employing the isolated spin pair approximation.

To obtain a NMR-derived ensemble, MD- $\operatorname{tar}^{25}$ simulations were performed for compounds $\mathbf{2}-\mathbf{4}$ employing a protocol identical to that described by Asensio et al. ${ }^{16}$ NOE-derived distances were included as time averaged distance constraints, and scalar coupling constants, as

(38) Pople, J. A. et al. Gaussian-94; Gaussian, Inc.: Pittsburgh, PA, 1995.

(39) Cornell, W. D.; Cieplack, P. C.; Bayly, I.; Gould, I. R.; Merz, K.; Ferguson, D. M.; Spellmeyer, D. C.; Fox, T.; Caldwell, J. W.; Kollman, P. A. J. Am Chem. Soc. 1995, 117, 5179-5197.

(40) Woods, R. J.; Dwek, R. A.; Edge, C. J.; Fraser-Reid, D. J. Phys. Chem. 1995, 99, 3832-3839.

(41) Haselhorst, T.; Weimar, T.; Peters, T. J. Am. Chem. Soc. 2001, 123, 1070510714. time averaged $J$ coupling constraints. A $\left\langle r^{-6}\right\rangle^{-1 / 6}$ average was used for the distances, and a linear average was used for the coupling constants. For derivatives $\mathbf{2}$ and $\mathbf{4}$, final trajectories were carried out using explicit solvent, counterions, periodic boundary conditions (PBC) and Ewald sums for the treatment of electrostatic interactions. An exponential decay constant of $500 \mathrm{ps}$ and simulation lengths of $5 \mathrm{~ns}$ were employed.

For compound $\mathbf{3}$, the experimental data could only be quantitatively reproduced after (in vacuo $\epsilon=80$ ) 80 ns MD-tar simulations. Preliminary tests showed that, for this flexible molecule, the use of exponential decay constants shorter than 5 ns produced unstable trajectories and led in some cases to severe distortions of the sugar rings. This problem could be solved by increasing the exponential decay constant value to $8-10 \mathrm{~ns}$. It has been estimated that simulation lengths of ca. 1 order of magnitude larger than the exponential decay constant should be used to generate reliable estimates of average properties. Therefore the final simulation length used was $80 \mathrm{~ns}$. We would like to point out that for MD-tar runs the sensitivity of the results to the simulation conditions (solvent, counterions, cutoffs, dielectric constant, etc.) used is extremely dependent on the amount of experimental information included as time-averaged constraints. For derivative $\mathbf{3}$ we employed 23 distance constraints and $7 J$ values. Under these conditions, the conformational regions sampled by the trajectory (within the esterically allowable regions) are mainly determined by the constraints, and the fine details of the simulation are not critical. In fact similar results were obtained using $\epsilon=40$ and $\epsilon=20$.

Finally, to further clarify the conformational properties of $\mathbf{3}$, we performed additional calculations. Thus, a geometry representative of each of the five most populated conformational families present for derivative 3 in solution, according to the in vacuo $\epsilon=80$ MD-tar calculations, was subjected to $5 \mathrm{~ns}$ unconstrained MD simulations in the presence of explicit water, counterions, periodic boundary conditions, and Ewald sums for the treatment of electrostatic interactions. The obtained trajectories show that, as deduced from the in vacuo MDtar simulations, the macrocyclic structure of compound $\mathbf{3}$ is compatible with wide fluctuations around the glycosidic linkages, different puckerings for ring III and different orientations for the three methylene bridge. In fact, the conformational regions populated by $\mathbf{3}$ according to these simulations are similar those deduced from the in vacuo $80 \mathrm{~ns}$ MD-tar trajectories (Figure S7).

Binding Experiments. The labeled 27mer A-site model was obtained in its polyacrylamide gel electrophoresis- (PAGE-) purified sodium salt form from Dharmacon Research, Inc. (Lafayette, CO). Buffer conditions for the binding experiments were $100 \mathrm{mM} \mathrm{NaCl}, 10 \mathrm{mM}$ sodium phosphate $(\mathrm{pH}$ 7.6). Fluorescence experiments were conducted on a Fluorolog-3 spectrophotometer (Jobin Yvon-Spex Instruments S.A., Inc., New Jersey) equipped with a thermostat. A quartz cell with a 1 $\mathrm{cm}$ path length in both the excitation and emission directions was used in all the experiments that were performed at $25{ }^{\circ} \mathrm{C}$. The RNA concentration was, in all cases, $1 \mu \mathrm{M}$ in strand. For renaturing the RNA, it was placed in a water bath at $20^{\circ} \mathrm{C}$, heated to $85^{\circ} \mathrm{C}$ for $1 \mathrm{~min}$ and then slowly cooled back to $20^{\circ} \mathrm{C}$ over a $2 \mathrm{~h}$ period. With the excitation wavelength set to $310 \mathrm{~nm}$, the change in the fluorescence emission at $369 \mathrm{~nm}$ upon complex formation was followed in titration experiments. Aliquots of the antibiotic derivatives were added sequentially, and 2 min of equilibration time were allowed before each fluorescence measurement. Fluorescence intensities were corrected for volume changes according to the following equation: $F_{i, \mathrm{corr}}=F_{i, \mathrm{obs}} * V_{i} / V_{o}$ where $F_{i, \text { corr }}$ is the corrected intensity for point $i$ of the titration, $F_{i, \mathrm{obs}}$ is the measured intensity at point $i, V_{i}$ is the volume after the $i^{\text {th }}$ addition and $V_{o}$ is the initial volume (typically $2 \mathrm{~mL}$ ). The $\mathrm{Kd}$ values for simple binding were determined by plotting $F_{i, \text { corr }}$ against the ligand to RNA ratio. In all cases, the data were found to fit well assuming a $1: 1$ complex.

Cloning, Overexpression, and Purification of the Aminoglyside Modifying Enzymes. The plasmid codifying for the AAC(2')-Ic from Mycobacterium tuberculosis was kindly provided by J. S. Blanchard 
(Albert Einstein College of Medicine, New York). This plasmid was transformed in the E. coli strain BL21(DE3). The expression and purification of Mycobacterium tuberculosis $\mathrm{AAC}\left(2^{\prime}\right)$ was performed as described by J. S. Blanchard and co. ${ }^{42}$

Enterococcus faecalis APH(3') and Staphylococcus aureus ANT(4') were subcloned from the plasmids pACYC177 and pBBR1MCS-2, respectively. PCR amplifications were performed in a $100 \mu \mathrm{L}$ reaction mixture containing DNA ( $3 \mu \mathrm{L})$ of the plasmids as a template, water $(70.5 \mu \mathrm{L})$, buffer (100 mM Tris-HCL, $500 \mathrm{mM} \mathrm{KCl}, \mathrm{pH} 8.0,10 \mu \mathrm{L})$, $\mathrm{MgCl}_{2}(2 \mathrm{mM}, 8 \mu \mathrm{L})$, dNTPs $(200 \mu \mathrm{M})$, primers $(1 \mu \mathrm{M})$, and Taq DNA polymerase (2.5 U). The primers employed for Enterococcus faecalis $\mathrm{APH}\left(3^{\prime}\right)$ were $\mathrm{Nt}$ (NdeI) (5'tataacatatgagccatattcaaggg3') and Ct (EcoR I)- (5'ttatagaattcttagaaaaactcatc $\left.3^{\prime}\right)$, and those used for Staphylococcus aureus $\mathrm{ANT}\left(4^{\prime}\right)$ were $\mathrm{Nt}($ Hind III)(5'gccgcaagattctgaatggaccaataata3') and $\mathrm{Ct}(\mathrm{Xho} \mathrm{I})$ (5'gectcgagtcaaaatggtatgcgttt3'). The reaction was subjected to 30 cycles of amplification. The cycle conditions were set as follows: denaturation at $94{ }^{\circ} \mathrm{C}$ for $1 \mathrm{~min}$, annealing at $50{ }^{\circ} \mathrm{C} / 1.0$ min for Enterococcus faecalis $\mathrm{APH}\left(3^{\prime}\right)$, and $55^{\circ} \mathrm{C} / 1.0 \mathrm{~min}$ for Staphylococcus aureus ANT (4') and elongation at $72{ }^{\circ} \mathrm{C}$ for $1 \mathrm{~min}$. The genes obtained from the PCR were purified with the Wizard PCR Preps DNA Purification System (Promega) and ligated in pET-28b $(+)$. The pET28b-APH3' and pET28b-ANT4' expression vectors constructed in this way were then transformed into $E$. coli BL21(DE3) competent cells.

Selected clones for Enterococcus faecalis $\mathrm{APH}\left(3^{\prime}\right)$ and Staphylococcus aureus ANT(4') were grown on $100 \mathrm{~mL}$ of LB medium containing $26 \mu \mathrm{g} / \mathrm{mL}$ kanamycin at $37^{\circ} \mathrm{C}$. When the cell growth reached an optical density at $600 \mathrm{~nm}\left(\mathrm{OD}_{600}\right)$ of 0.5 , the temperature was switched to $30{ }^{\circ} \mathrm{C}$ and the culture was induced with $0.5 \mathrm{~mm}$ IPTG. After $24 \mathrm{~h}$ of induction, the expression level was analyzed by SDSPAGE using gels with $13 \%$ polyacrylamide in the separation zone. Proteins were purified employing a $\mathrm{Ni}^{2+}$-IDA-agarose column. The enzymes after this step were found to be more than $90 \%$ pure as assessed by SDS-polyacrylamide gel electrophoresis.

Enzymatic Activity. Enzymatic reactions were performed in NMR tubes. The nucleoside triphosphate (ATP $100 \mu \mathrm{M}-3.0 \mathrm{mM}$ ) and the aminoglycoside $(100 \mu \mathrm{M}-1.5 \mathrm{mM})$ were dissolved in $10 \mathrm{mM}$ phosphate buffer, $\mathrm{pH} 7.0,2.5-5.0 \mathrm{mM} \mathrm{MgCl}_{2}$. After addition of the enzyme (0.2-

(42) Hegde, S. S.; Javid-Majd, F.; Blanchard, J. S. J. Biol. Chem. 2001, 276, $49,45876-45881$
$20 \mu \mathrm{M})$, the evolution of the reaction mixture at $37^{\circ} \mathrm{C}$ was monitored by $1 \mathrm{D}^{1} \mathrm{H} \mathrm{NMR}$, and the final products were characterized by $2 \mathrm{D}$ NMR and MALDI-TOF MS.

Biological Activity. Minimal inhibitory concentrations (MIC) were measured according to a published method. ${ }^{43}$ The different bacteria were grown in $1 \mathrm{~mL}$ of Mueller-Hinton broth to an optical density $\mathrm{OD}_{600}$ of 0.5 units. The desired concentrations of antibiotic were added from stock solutions. The samples were incubated at $37{ }^{\circ} \mathrm{C}$ for $24 \mathrm{~h}$. After this time the control culture (with no antibiotic) had an $\mathrm{OD}_{600}$ of 1.2-1.6. Then the $\mathrm{OD}_{600}$ of each sample was read, and the MIC was taken as the lowest antibiotic concentration inhibiting bacterial growth by greater than $90 \%$.

To determine the effect that expression of $\mathrm{AAC}\left(2^{\prime}\right)$ has on the MIC values the previously described protocol was slightly modified. The different bacteria were grown in $1 \mathrm{~mL}$ of Mueller-Hinton broth to an optical density $\mathrm{OD}_{600}$ of 0.3 units. The temperature was switched to $30{ }^{\circ} \mathrm{C}$, and the culture was induced with $0.5 \mathrm{~mm}$ IPTG. When the $\mathrm{OD}_{600}$ reached 0.5 units, the desired concentrations of antibiotic were added from stock solutions. The samples were incubated at $30^{\circ} \mathrm{C}$ for $24 \mathrm{~h}$, and the MIC was taken as the lowest antibiotic concentration inhibiting bacterial growth by greater than $90 \%$.

Acknowledgment. We thank Prof. J. Blanchard (Albert Einstein College of Medicine, New York) for supplying the plasmid encoding Mycobacterium tuberculosis AAC(2'). Financial support from DGES (Grant CTQ2004-04494) is gratefully acknowledged. F.C. thanks Comunidad Autónoma de la Rioja for a postdoctoral fellowship. M.T. thanks the Ministerio de Educación y Ciencia for a predoctoral fellowship. The authors thank CESGA (Santiago de Compostela) for computer support.

Supporting Information Available: Synthesis of derivatives 4 and 5. Supplementary Figures S1 to S7 showing NMR spectra of aminoglycosides 2-6 and solvated MD simulations for derivative 3. This material is available free of charge via the Internet at http://pubs.acs.org.

JA0543144

(43) Waterworth, P. M. In Laboratory Methods in Antimicrobial Chemotherapy Garrod, L., Ed.; Churchill Livingstone Press: Edinburgh, 1978; pp 3140 